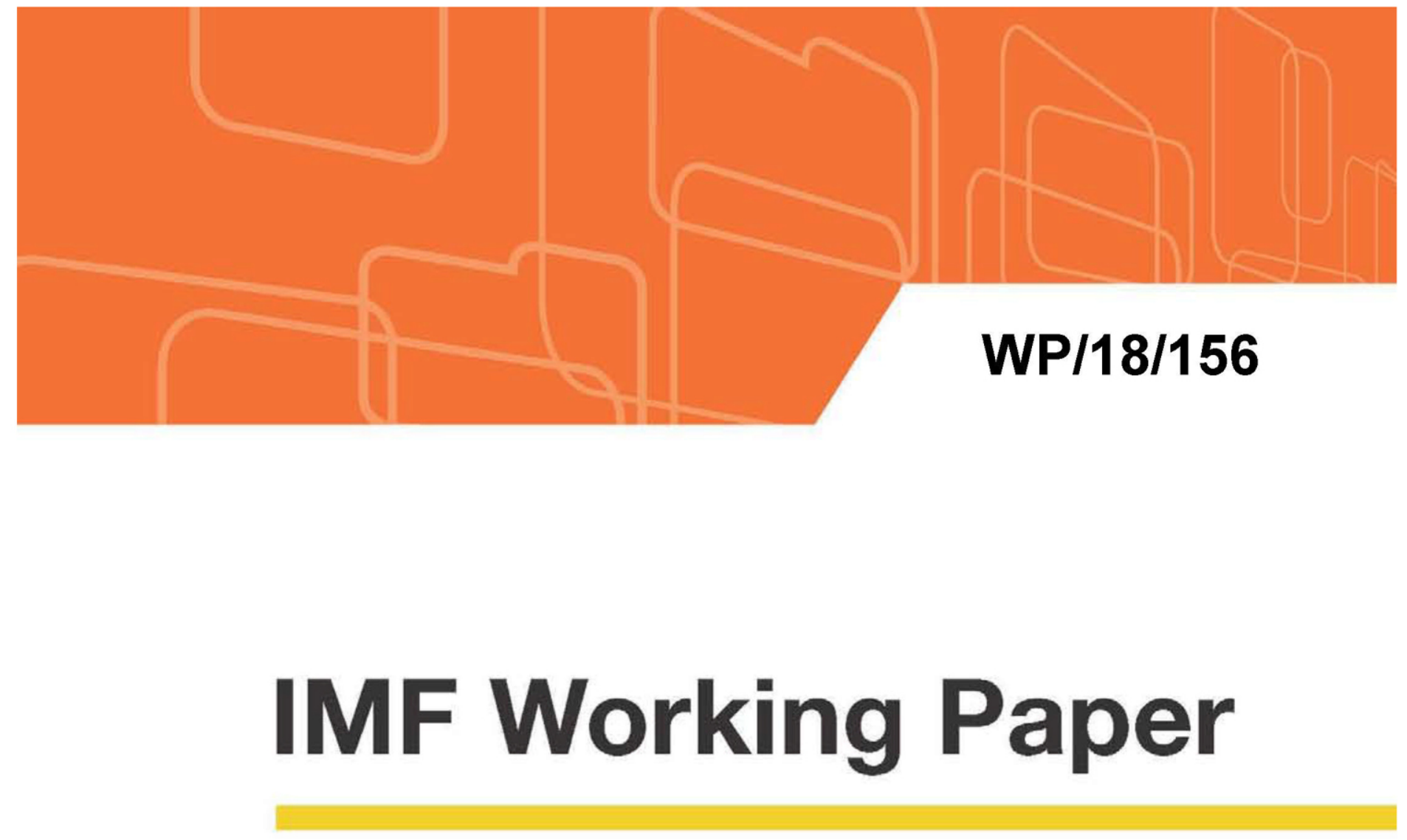

\title{
Central Bank Communication and Monetary Policy Surprises in Chile
}

by Andrea Pescatori

IMF Working Papers describe research in progress by the author(s) and are published to elicit comments and to encourage debate. The views expressed in IMF Working Papers are those of the author(s) and do not necessarily represent the views of the IMF, its Executive Board, or IMF management. 


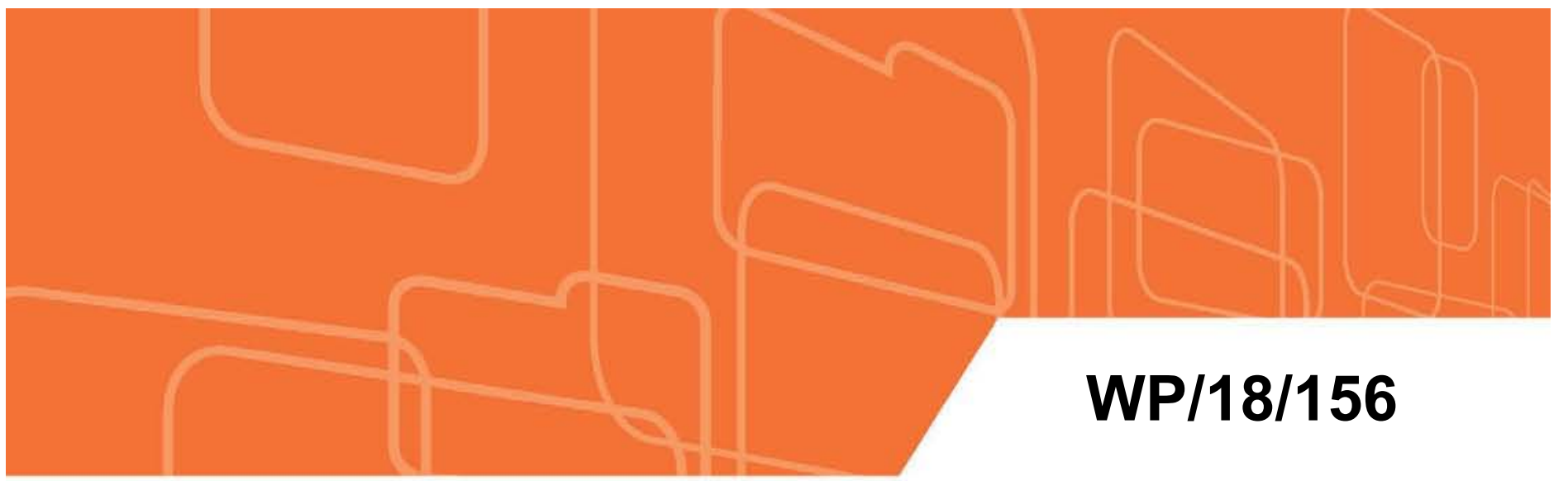

\section{IMF Working Paper}

\section{Central Bank Communication and Monetary Policy Surprises in Chile}

by Andrea Pescatori

IMF Working Papers describe research in progress by the author(s) and are published to elicit comments and to encourage debate. The views expressed in IMF Working Papers are those of the author(s) and do not necessarily represent the views of the IMF, its Executive Board, or IMF management. 


\title{
IMF Working Paper
}

Western Hemisphere Department

\section{Central Bank Communication and Monetary Policy Surprises in Chile}

\section{Prepared by Andrea Pescatori}

Authorized for distribution by Luca Ricci

July 2018

\section{IMF Working Papers describe research in progress by the author(s) and are published to elicit comments and to encourage debate. The views expressed in IMF Working Papers are those of the author(s) and do not necessarily represent the views of the IMF, its Executive Board, or IMF management.}

\begin{abstract}
This paper assesses the quality of the $\mathrm{CBC}$ 's communication policy by looking at the predictability and effectiveness of monetary policy communications by the Central Bank of Chile (CBC). To do so, we construct indeces of monetary policy surprises for the three major communication channels of the CBC: the release of policy meetings' statements, minutes, and monetary policy reports (IPoM). We assess monetary policy predictability and efficacy by looking at the size and time-evolution of monetary policy surprises associated with meeting statements and the impact of the above communication channels on asset markets. We find that, in general, the CBC's has been effective in its forward guidance through its statements and IPoM. Policy actions are quite predictable, especially post the global financia crisis. The response of equity prices and the exchange rate to monetary policy surprises have the right sign but are not robust. We also find an asymmetric response of equity prices to minutes suggesting that market participants extract information on the status of the economy especially when minutes have a loosening effect. Finally, to look at the macroeconomic impact we find that a 100 bps monetary policy tightening shock implies a decline in economic activity (IMACEC) of about $2 \mathrm{pp}$. after one year, while the response of inflation is more muted.
\end{abstract}

JEL Classification Numbers: E3, E44, E52, E58

Keywords: Monetary policy; monetary policy shocks; proxy VAR; central bank communication; central bank predictability; inflation forecast dispersion, Chile.

Author's E-Mail Address: apescatori at imf dot org 


\section{INTRODUCTION ${ }^{1}$}

Just a few decades ago, conventional wisdom in central banking circles held that monetary policymakers should say as little as possible and say it cryptically (Blinder et al 2008). Much has changed since then; as it became increasingly clear that accountability and managing private sector expectations are vital for an independent central bank, communication policy rose in stature from a nuisance to a key instrument in the central banker's toolkit.

Historically, it was the tendency for independent central banks to become more accountable that initially fostered the development toward increased transparency. The latter is a means of enhancing the credibility of the central bank's commitments which is critical for managing private sector expectations. Transparency, furthermore, enhances not just policy credibility but also policy flexibility. Central bank transparency is also a way of enabling markets to respond more smoothly to policy decisions. When a central bank is more transparent about its economic outlook and about how that outlook is related to its policy stance, monetary policy decisions are less likely to come as a surprise and cause sharp movements in asset prices that may create financial distress.

One important tool to achieve transparency is communication with the public. Moreover, the global financial crisis (GFC) and its aftermath have shown how central banks that want to shape private sector expectations by providing forward guidance need an effective communication toolkit. As a result, many central banks now place great emphasis on their communication policy.

While there are various useful qualitative metrics to evaluate and rank the degree of transparency of a central bank (Dincer and Eichengreen 2013), it is more challenging to assess the effectiveness of short-run communication policies and their ability to affect private sector expectations. ${ }^{2}$

In this paper, we analyze the effects of various communication channels available to the Central Bank of Chile (CBC). More specifically, first, we assess the predictability of monetary policy actions which is a necessary (but not sufficient) condition for a good and credible communication policy. Second, we assess the efficacy of the CBC's monetary policy by looking at how yields, equity prices, and the exchange rate react to statements, meetings' minutes, and monetary policy reports. Efficacy and predictability reinforce each other and jointly are an indication of an effective communication policy, especially in relation to forward guidance. Finally, we also look at the macroeconomic impact of monetary policy shocks on economic activity and inflation.

\footnotetext{
${ }^{1}$ I am grateful to Pablo Garcia, Mario Marcel, and Alberto Naudon for valuable comments as well as seminar participants at the Central Bank of Chile. I thank Luca Ricci for his precious guidance and Martin Sasson for excellent research assistance. All errors are mine.

${ }^{2}$ Long-term communication strategies - which include announcing the central bank's long-term goals and mandates - have been studied extensively (Ball and Sheridan 2004 and Mishkin and Bernanke 1997, among others) and are beyond the scope of the paper.
} 
Our analysis relies on constructing various series of monetary policy surprises by using survey forecasts of the policy rate and by measuring the short-term rate impact of communication events such as the release of the monetary policy report (IPoM) and meetings' minutes. ${ }^{3}$ Monetary policy surprises associated with policy decisions at the regular meetings are the un-anticipated movement in the monetary policy rate based on both the central bank's and Bloomberg's survey. This is similar in spirit to Kuttner (1997), Bernanke and Kuttner (2005), Gertler and Karadi (2015), and Gurkaynak et al (2005) for the US, and Meyer (2006), Garcia-Herrero et al (2017) and Larraín (2007) for Chile even though their analysis exploit policy rate futures markets or intraday data. ${ }^{4}$ Similarly, we construct the impact of IPoMs, statements, and minutes on the yield curve by looking at the daily change of yields (and swap rates) at different maturities the day of the event. (Yields and swap rates are first regressed on a set of controls to reduce noise).

Our results for Chile can be summarized as follows.

The predictability of policy decisions has been relatively high except for 2009 where the CBC cut rates substantially faster than expected. ${ }^{5}$ Predictability has also increased over time as the number of surprise meetings has declined as has the overall number of meetings with a change in the policy rate-even though macroeconomic volatility has not changed meaningfully. ${ }^{6}$ The mean absolute monetary policy surprise has in fact decreased from about 2 bps per meeting pre GFC to less than 1 bps post GFC - predictability is modestly better than for the US Federal Reserve during the 1998-2012 period (standardized for the relative policy rate volatility). Finally, monetary policy surprises are positively correlated to inflation expectations, 0.46 , which is evidence of the CBC's commitment to aggressively move rates if inflation expectations move away from the target.

The efficacy of statements at times of monetary policy surprises is quite high since monetary policy surprises also significantly affect the medium- and long-end of the yield curve. Also, forward guidance from statements seems to shift the entire yield curve, while surprise actions tend to tilt the short-end rather than shift the curve. ${ }^{7}$ The IPoM also provides substantial

\footnotetext{
${ }^{3}$ We do not analyze the impact of board member speeches which is left for future work.

${ }^{4}$ Larraín (2007) finds similar results using interest rate futures and surveys, for Chile. Meyer (2006) uses Bloomberg surveys and find a $6.5 \mathrm{bps}$ increase in the 5 -year yield after a $25 \mathrm{bps}$ surprise. Garcia-Herrero et al (2017) focuses on the impact of surprises on interest rate volatility while Moreno et al (2015) analyze the comovement between asset classes in presence of monetary policy (and other) shocks. Data limitations and some specificity of the Chilean policy communication framework do not allow us to use intraday data.

${ }^{5}$ For a similar analysis on the pre-GFC period see also Larraín (2007).

${ }^{6}$ The coefficient of variation for GDP growth is higher between 2011 and 2017 relatively to the pre-GFC period (2003-2008), 0.97 versus 0.85 , respectively. The one for inflation is lower 0.88 versus 1.17 , respectively.

${ }^{7}$ This result is broadly in line with Gurkaynak et al (2005) who find that forward guidance on future policy rates accounts for more than three quarters of the total effect on longer maturity interest rates.
}

(continued...) 
forward guidance for the policy rate inducing changes in medium- and long-term yields superior even to the ones induced by "surprise" meetings suggesting that the policy information content of the IPoM is useful and significant. ${ }^{8}$ An analog analysis does not find a similar result for minutes, instead, suggesting that minutes provide relatively little forward guidance other than what was already in the statement.

We also study the impact of monetary policy surprises on stock and FX markets. A 100 bps tightening surprise typically causes an exchange rate appreciation by about 1.5 percent in the same day of the surprise. The reaction of equity prices, in contrast, is not significant, though with the correct sign. Both results, however, are not robust. ${ }^{9}$ Interestingly, even though minutes have a more modest effect on the yield curve they seem to have some effect on the stock market, although asymmetrically: contrary to intuition, "dovish" minutes (i.e., the minutes decreases the 3-month swap rate on the release date) have a negative impact on equity prices. This result suggests that the information content of dovish minutes probably include information over state of the economy (i.e., a negative economic outlook) rather than the CBC's Board's member preferences for looser monetary policy per se. IPoMs and surprises also seem to affect inflation-forecast dispersion, but only conditional on a "hawkish" tone: a 25 bps tightening surprise induced by the release of minutes reduces inflation-forecast dispersion by 0.15 points.

Finally, using a proxy-VAR a la Gertler and Karadi (2015), we find that a 100 bps monetary policy tightening shock induces a hump-shaped response for the policy rate and a reduction in economic activity with a peak decline in the IMACEC of about 2 pp. after 1 year. In contrast, the CPI's response shows an initial increase (i.e., "price puzzle") that reverts after about 2 months and makes the CPI 1 percent lower after 2-3 years.

The paper is divided as follows: in Section II we describe the central banks of Chile's institutional framework; in Section III we present the data and methodology; in section IV we describe monetary policy predictability; in Section V and VI we study efficacy (including forward guidance) by showing the impact on the yield curve, equity prices and the exchange rate; in Section VII we study the impact on inflation-forecast dispersion; in Section VIII we present the impact of the identified monetary policy shocks on the real activity and inflation; in Section IX we conclude.

\section{The CENTRAL BANK OF CHILE INFLATION-TARGETING FRAMEWORK}

After a period of inflation convergence in the 1990s - when inflation declined steadily from double to low single digits - in September 1999, Chile coupled its inflation targeting (IT) regime with a free-floating exchange rate regime. The ensuing period was characterized by low and stable medium-term inflation expectations. We, thus, focus our analysis on the post-

\footnotetext{
${ }^{8}$ The IPoM can shift the yield curve while surprise statements mostly affect the slope of the yield curve.

${ }^{9}$ Using intraday data Ranaldo and Rossi (2010) finds a significant effect on the Swiss Franc and Swiss stock market after monetary policy announcements, speeches and interviews of the Swiss National Bank. Similarly, for the U.S. Rosa (2010) finds significant effects of Federal Reserve's decisions and statements on US stocks (not dissimilar to Bernanke and Kuttner 2005).
} 
convergence period. Below we briefly summarize some of the salient features of the CBC's IT regime.

The CBC ranks high on the transparency index (see Dince and Eichengreen 2013) and has a clear "long-run" communication policy underpinned by a well-defined single mandatespelled out every month in the preface of its monetary policy report. The mandate has changed over time but only very modestly. In early 2000s, the CBC had adopted a 2-4 percent band for CPI inflation over a 12- to 24-month horizon without specifying a mid-point target. Since 2007, instead, the CBC has regularly clarified that it is committed "to keep annual CPI inflation at around 3 percent most of the time, within a range of plus or minus 1 percentage point. To meet this target, the Bank focuses its monetary policy on keeping projected inflation at 3 percent annually over a policy horizon of around two years." (CBC, 2017).

During our sample period, the $\mathrm{CBC}$ has held monetary policy meeting regularly every month. Each meeting is followed by a short statement that provides a succinct rationale of the policy decision while minutes of the meetings are released with delay (see below).

The meeting's Statement is published in Spanish following each monetary policy meeting, stating the decision, explaining recent developments, and the expected future evolution of key variables and risks. Almost half the statements issued since 2011 have included clear and concise guidance about the likely future path of monetary policy, and the statements are explicitly conditional on current forecasts. ${ }^{10}$

Minutes of the monetary policy meeting are released with a two-week delay since 2006 (before it was 45 days). With respect to the statement, minutes have traditionally included additional information about the details of the meeting discussion, including on the outlook, the policy alternatives that were considered, the arguments presented by Board members, and the balance of votes.

The Monetary Policy Report (IPoM) is the Board's main communication tool that provides a detailed explanation of the economic outlook and the rationale behind policy decisions (De Gregorio 2008). It is released quarterly in Spanish and English. Each report clearly states that the policy objective is to bring inflation to target within the policy horizon of two years, and the document sets out to explain how the Board intends to meet this target. The report also includes key forecasts, such as growth and inflation fan charts, and provides (infrequently) estimates of unobservable variables such as the potential growth rate. The report does not provide a policy rate fan chart.

In the next section we will assess the yield curve impact of the release of the statements, minutes, and IPoM. We will also look at surprise movements in the policy rate.

\footnotetext{
${ }^{10}$ Since September 2017, statements also include information on the arguments made by Board members, and their votes. The statement issued on February 1, 2018 was the first to implement the new format, and was 3.5 times longer than the average statement from 2017. Being outside our sample, this, however, does not affect our analysis.
} 


\section{DATA AND METHODOLOGY}

\section{Data}

We construct a dataset with release dates of monetary policy statements, monetary policy meetings' minutes, and monetary policy reports (IPoM). The statement is published at $6 \mathrm{pm}$ right after the monetary policy meeting and after markets close. Minutes of the policy meeting were released with 45 days delay before 2006 and subsequently with 15 (11 business) days delay. The IPoM is released 4 times a year starting in March at the beginning of the month, usually in the morning. It is released jointly with the statement only since January 2018 (outside our sample). ${ }^{11}$

To analyze the effect on the fixed-income market we use swap rates (Figure 8) - and for robustness we use yields of government bond and central bank notes. Looking at the series suggests that for maturities of up to one year, central bank yields might be more reliable than swap rates but for longer maturities swap rates are less erratic than yields.

Survey data are from the central bank (Encuesta de Expectativas Económicas, for short EEE) and the Bloomberg expectation survey, and both are filed every month. ${ }^{12}{ }^{13}$ The EEE is a survey of professional forecasters and is usually released a week or so before the policy meeting and the CPI release, but we have found 5 exceptions in our sample. ${ }^{14}$ Between 2003 and 2017, we have a total of 180 monetary policy meetings (i.e., statements and minutes) and 53 IPoMs. Only in two cases (Dec 2009 and Jun 2010), the IPoM and the statement were on the same day. For June 2010 this coincided with a monetary policy surprise. ${ }^{15}$

\footnotetext{
11 The statement of each monetary policy meeting is published on the website at 6:00 pm on the day of the meeting. The minutes are published at 8.30 am (11 business days after the policy meeting since 2006). Since 2018, the monetary policy reports (IPoM) will be published on the central bank website at 8.a.m. of the day immediately following the monetary policy meetings of March, June, September and December. It is worth noting that the number of IPoM releases has changed over time. Between 2003 and 2008 there were 3 releases a year while before 2003 the number of releases was irregular.

12 The EEE can be found on the CBC's webpage at http://www.bcentral.cl/en/expectativas-economicas.

${ }^{13}$ A typo has been corrected in the June 2007 Bloomberg survey (we change the max value for the monetary policy rate from 9 to 6). In 5 instances (9/8/2003, 9/9/2008, 4/9/2009, 5/11/2009, and 9/10/2009) the EEE seems to have been filled before the monetary policy meeting.

14 The exceptions are the releases of 9/8/2003, 9/9/2008, 4/9/2009, 5/11/2009, and 9/10/2009 when the EEE survey was released after the monetary policy meeting, implying that forecasters might have already known the outcome of the policy meeting.

${ }^{15}$ Only in December 2009 and June 2010 the IPoM was released the day after the statement, which implies that their market impact is not identifiable under our strategy.
}

(continued...) 


\section{FX interventions}

Since the adoption of a fully flexible exchange rate regime, the CBC intervened in the FX market to stabilize the peso only on two major occasions in 2008 and $2011 .{ }^{16}$ The interventions were very predictable with the stated goal of increasing the size of international reserves in a situation where the Chilean peso was strong.

In the first intervention, on April 10 at the end of the ordinary monetary policy meeting after market close, the CBC announced a program to accumulate reserves of up to USD 8 billion through the remainder of that year. The program was, however, suspended at the end of September, after the demise of Lehman Brothers, when the Central Bank had accumulated about USD 5.75 billion. On the day after the announcement, the peso moved little while yields declined mildly at short term maturities, and the stock market gained modestly. Two business days after, however, the exchange rate depreciated by more than 3 percent.

In the second intervention, on January 4, 2011, with an extraordinary meeting, the CBC announced FX interventions that would last a year and consisted in buying USD 12 billion in the spot market at an average of USD 50 million per day. By the end of 2011, foreign reserves had climbed to more than USD 40 billion, equivalent to $17 \%$ of GDP. After the announcement the (multilateral) exchange rate appreciated by about 4 percent. The stock market improved and the short-term rates declined but the impact on long-term rates was more mixed. In both cases, it seems that portfolio effects were relatively modest while the signaling was more visible.

We, thus, introduce two dummies to control for announcements of FX interventions in our regressions (see next section).

\section{Methodology}

We exploit a high frequency identification to construct series of monetary policy and forward guidance surprises following a long-standing tradition (e.g., Kuttner (2001), Gürkaynak et al (2005), Gertler and Karadi (2015), and Larraín (2007) for Chile, among others). We then use the constructed surprise series to assess and evaluate the CBC's communication policy. To that end, it is useful to introduce a conceptual framework where communication is assessed in terms of predictability and efficacy (Blinder et al 2008).

Predictability. Unconditional predictability can be defined, loosely speaking, as the inverse of the absolute policy rate surprise at the day of the meeting. ${ }^{17}{ }^{18}$ There are clearly various

\footnotetext{
${ }^{16}$ We exclude the FX interventions between 2001 and 2002 since these are outside our sample.

${ }^{17}$ In a similar spirit, Ehrmann and Fratzscher (2007) defines predictability as the absolute mean change in the 1month yield at the day of the meeting.

${ }^{18}$ Ideally monetary policy should be conditionally predictable: Economic developments should make policy decisions predictable, rather than having the central bank hinting their next move: "A transparent monetary
}

(continued...) 
approaches for calculating monetary policy surprises. Here, we focus on the difference between the policy rate decided at the meeting and its survey forecast for that meeting. This means the time difference between when forecasts are made and the policy decision is taken should be short enough to avoid relevant information to be released between the time forecasters filled the survey and the policy meeting. ${ }^{19}$

We construct the surprise series using the median, mean, maximum, and minimum monetary policy rate's expectation from the Bloomberg survey (for the CBC's surveys we only have the median forecast). It is, thus, possible to decompose any policy change in its anticipated, $i_{t}^{a}$, and un-anticipated, $i_{t}^{u}$, components for each forecast $j$

$$
\Delta i_{t}=i_{t}-E_{j, t-1} i_{t}+E_{j, t-1} i_{t}-i_{t-1}=\Delta i_{j, t}^{u}+\Delta i_{j, t}^{a}, \text { for all } j
$$

where $E_{j, t-1} i_{t}$ is the forecast-j, from the surveys above mentioned. We calculate the mean, $\Delta i_{a, t}^{u}$, median, $\Delta i_{m, t}^{u}$, maximum (i.e., the most dovish), $\Delta i_{d o v, t}^{u}$, and minimum (i.e., the most hawkish), $\Delta i_{\text {hak,t }}^{u}$, un-anticipated policy changes (i.e., surprises) across forecasts. It is, thus, intuitive to define predictability as the inverse of the unanticipated policy change which can be approximated, for example, by the inverse of the average-forecast surprise.

Efficacy. This is defined as the market reaction to policy actions and events. In general, it is hard to know whether a market reaction was intended or not (the 2015 taper tantrum in the United States is an example of unintended efficacy). In practice, a credible central bank should be able to affect both short- and long-term yields through its communication channels, such as minutes, statements, and monetary policy reports. High efficacy should also increase predictability as markets are better able to anticipate central bank intentions. In practice, we will infer efficacy by looking at the yield curve, equity, and FX markets responses at times of central bank's release of statement, minutes, and IPoM.

Specifically, to assess efficacy, we first regress changes in yields on a set of control variables to reduce possible noise.

$\Delta i_{t}^{m}=c_{0, t}+c_{1} \Delta i_{t}^{m, U S}+c_{2} i_{t-1}^{10 y, U S}+c_{3} i_{t-1}^{1 m, U S}+c_{4} \Delta \ln \left(p_{c, t}\right)+c_{5} \Delta C D S_{t}+c_{6} \Delta E M B I_{t}+\varepsilon_{t}^{m}$

The idea is to control for factors that affect yields but are orthogonal (given our timing identification) to the policy rate decision. We divide the factors into three groups 1) US

policy reaction function means that the news should be in the developments of the economy not in the announcements of decisions by the central bank" (King 2000); hence, a successful central bank should be boring. In modelling terms, this is equivalent to assume that the systematic component of the monetary policy rule is perfectly observable by economic agents.

19 The EEE is usually filled 2-4 weeks prior to the next monetary policy meeting while the Bloomberg survey is released a few days before the meeting. 
interest rates, 2) copper prices, and 3) country risk. We also add two dummy variables for the 2008 and $2011 \mathrm{FX}$ interventions and a possible time-trend in $\boldsymbol{c}_{\mathbf{0}, \boldsymbol{t}}$.

In the next section we will assess the CBC's predictability and how it has evolved over time. In section $\mathrm{V}$ we will turn to efficacy.

\section{PREDICTABILITY}

The monetary policy rate has fluctuated substantially within our sample period from 0.5 percent in 2004 to 8.25 percent in 2008 . Even so, a casual observation shows that monetary policy surprises have been relatively modest - except during the GFC where the policy rate was cut by almost 800 bps in seven months - and less frequent in the most recent period (Figure 1). In this section, we will verify more precisely these casual observations and provide a descriptive analysis of surprises stemming from monetary policy meetings over the 2003-2017 sample period.

Of the 180 monthly meetings between 2003 and 2017, 60 had a policy rate change, one every 3 meetings. Out of these 180 meetings, the median forecaster has been "surprised" 27 times (i.e., 15 percent of the time or about one every 7 meetings). ${ }^{20}$ Out of these 27 only in 6 occasions (about 5 percent of the times) forecasters were surprised by the TPM left unchanged (i.e., surprises conditional on a no policy change) — suggesting that the $\mathrm{CBC}$ is more likely to surprise markets and operators when it moves the policy rate.

The median-forecast surprise, however, masks forecast uncertainty and disagreement (Figure $2)$. Indeed, given the presence of forecast disagreement $\left(\Delta i_{\text {hak,t }}^{u} \neq \Delta i_{\text {dov,t }}^{u}\right)$, mean-forecast surprises are more frequent, being non-zero in about 55 percent of the meetings. Moreover, when the mean forecast is used, also the frequency of meetings without a policy rate change that have nonetheless surprised markets increases substantially from 5 to 40 percent while that one conditional on a policy rate change is up to 83 percent (Table I-A and I-B). It is also worth noting that only in 2 instances the $\mathrm{CBC}$ has miscommunicated and surprised the markets with a move even in presence of no disagreement among forecasters (Table I-B).

The distribution of mean and median forecast surprises is quite symmetric around zero but a few episodes during the GFC skew the distribution toward the left where we have 4 major loosening surprises above 50 bps (Figure 3 top charts). Indeed, the period of the GFC shows the biggest surprises in our sample. The biggest one is in February 2009 (150 bps). ${ }^{21}$ That surprise was preceded and followed by two other major loosening surprises that cumulated to

\footnotetext{
${ }^{20}$ The Bloomberg and EEE median surprises always point to the same direction and are of similar magnitudes which means that the two surveys provide very similar information. We will, thus, focus most of our attention on the results using the Bloomberg's survey.

${ }^{21}$ To put it into context, the biggest surprise for the Fed was in Feb 2018 with a -40bps (Gerlter and Karadi 2015).
} 
a total of 350 bps surprise for the first quarter of 2009. As a result, the average surprise during 2003-2017 has a noticeable loosening bias of about $-3 \mathrm{bps.} .^{22}$ For sake of comparability, the Fed has a similar loosening bias, once the Fed's surprises are standardized by the ratio of the standard deviations of the monetary policy changes. ${ }^{23}$ Beyond the GFC, it is also worth noting that hawkish forecasts have never been surprised by extra tightening while a few dovish forecasts have been surprised by extra loosening (Figure 3 bottom charts). ${ }^{24}$ This suggests that the $\mathrm{CBC}$, maybe because the sample is too short or business cycle is asymmetric, is more comfortable with loosening surprises rather than vice versa.

Notwithstanding the GFC, the average size of the surprises is relatively modest. The monthly mean absolute surprise for the mean (median) forecast is about 6 bps ( 5 bps) which is relatively small but still 3 bps higher than the one calculated for the US Federal Reserve (see Table I-A). ${ }^{25}$ This is again, in part driven by the 2009 events when the CBC probably acknowledged with a delay the need to provide monetary policy stimulus. This in part might be due to inflation expectations which moved up sharply in 2008. In fact, we find that monetary policy surprises are positively correlated to inflation expectations, 0.46 , which is evidence of the CBC's commitment to aggressively move rates if inflation expectations move away from the target (Figure 4 bottom panel).

The biggest surprises in Chile are clustered between 2008 and 2010-which is also the period of highest forecast disagreement (175 bps difference between the most dovish and hawkish forecast) - and are more frequent pre-GFC (the total number of median-forecast surprises has declined recently which in part is due to a decline in monetary policy changes, see Figure 4 top panel). Once we exclude 2009, the mean absolute surprise has decline over time from about 2 bps, between 2003 and 2008, to less than 1 bps, between 2010 and 2017 (Figure 4 top panel). Also, the only episodes of "miscommunications" refer to the pre-GFC period when the $\mathrm{CBC}$ surprised the markets in absence of forecast disagreement. ${ }^{26}$

In conclusion, the $\mathrm{CBC}$ has a relatively high predictability which in average has improved over time. In the next section we will analyze the efficacy of the CBC's policy actions and its communication policy.

\footnotetext{
${ }^{22}$ The sum of median- (mean-) forecast surprises between 2003 and 2017 is 526 (460) bps of which 350 (327) bps are concentrated in 2009.

${ }^{23}$ Calculated using GK for the period 1998-2012, caveat: not perfectly comparable, methodology is different and the Fed has 8 meeting per year.

24 The biggest tightening shock is only 25 bps using the median forecast and 50 bps using the most dovish forecast.

25 The mean (median) forecast absolute annual surprise is 48 (52) bps, and 28 (31) bps excluding 2009. This is lower than $6 \times 12=72 \mathrm{bps}$, as expected in absence of strong autocorrelation for the surprise series.

${ }^{26}$ In Jan 2004 and July 2007, the central bank surprised markets by cutting rates (by 50 and 25 bps, respectively) at a time when the Bloomberg survey expected no cuts and showed no forecast uncertainty.
} 


\section{EFFICACY: FIXED-INCOME MARKETS}

We first analyze how statements after monetary policy meetings (i.e., words and actions) affect swap rates at different maturities (i.e., yield curve).

Anticipated policy changes have no significant impact either on long-term rates nor on shortterm rates such as the 3-month swap rate. This differs starkly from the meetings where we have identified a surprise, in this case the impact on the swap rates is strong and highly significant (Figure 5). Regressions show that a 100 bps surprise increases the 3-month swap rate by about 53 bps and explains about 64 percent of its variation; the impact declines monotonically, as expected, and it is 7 bps for the 10 year rate (Table II). It is worth noting that the impact is much stronger than what a purely temporary (i.e., 1 month) movements in the policy rate would have implied. For example, if the monetary policy shock reflected only timing uncertainty over the monetary policy decision (e.g., raising the TMP this month vs. next month) it would have implied an impact of at most $33 \mathrm{bps}$ for the 3 -month rate and 0.8 bps for the 10 -year rate (almost $1 / 10^{\text {th }}$ of the observed one). The effects are stronger if we remove 2009Q1, raising the impact on the 3-month (1-year) rate to 76 (58) bps, but reducing the one on the 10-year rate (Table VIII-A and B). ${ }^{27}$

Not just actions (i.e., the policy rate decision per se) but also words in the statements have significant effects. In other words, we can focus on the occasions where there was no policy rate surprise (i.e. the market has perfectly anticipated the move), but there was a statement which was effectively forwards guidance (by describing the rationale for the decision and the bias); such forward guidance may have an impact on the yield curve. To test it, we regress the swap rates at various maturities on the 3-month rate using a dummy to condition on whether there was a surprise at the meeting (Table IX). ${ }^{28}$ Indeed, the effect is strong. The impact coefficient of the 3-month swap rate on yields in absence of surprises is bigger than 1 up to the 5-year yield and is still 0.9 and strongly significant for the 10-year yield. These high coefficients represent the pure forward guidance (i.e., communication) effect of statements since have been found in the absence of any surprise action. Forward guidance from statements seems to shift the entire yield curve while surprise actions tend to tilt rather than shift the curve.

Overall, the results suggest that $\mathrm{CBC}$ can affect private sector expectations not only at short and medium but also at longer horizons, working through the statement's forward guidance (in addition to the monetary policy actions). The effect of forward guidance seems greater during periods of heightened economic uncertainty such as the GFC.

We now focus our attention on IPoM and minutes. Since the policy rate is unchanged the day of the release of IPoMs and minutes we use the 3-month swap rate movements on that day.

\footnotetext{
27 The impact on the 1-year rate is stronger than Larraín (2008) who finds, over the 2002-2007 sample, a 35 bps effect.

${ }^{28}$ The regression has 138 observations, of which 59 were no surprise. The standard deviation of the 3-month swap rate conditional on (no) surprises is 16 (3) bps.
} 
Comparing Figure 5 with Figure 6, we see that statements had usually a stronger market impact than the IPoM and minutes but more recently - probably thanks to the increase predictability of CBC's monetary policy - the impact of statements is similar in magnitudes to the one of the IPoM and minutes.

Interestingly, Figure 6 also shows that swap rates strongly co-move the day of the IPoM's release while this is less clear-cut for minutes. Indeed, regressing swap rates at 6-month and higher maturity on the 3-month swap rate, on the day of the release, we find very high and significant coefficients (close to one at short-horizons but, as expected, declining with maturity). These coefficients are much stronger than control which is proxied by the typical reaction of longer-maturity swap rates to the 3-month rate over our sample period (Table III). This impact is also stronger than the one found for statements. This suggests that the IPoM has played an important role within the communication framework to implement CBC's forward guidance.

An analog analysis does not find a similar result for minutes suggesting that minutes provide relatively little forward guidance in addition to the one already present in the statement (Table IV). Also compared to the IPoM, the policy information content of the minutes is substantially less relevant for markets.

\section{EFFICACY: EXCHANGE RATE AND STOCK MARKET IMPACT}

A 100 bps tightening (statement) surprise typically appreciates the exchange rate at impact by about 1.5 percent while anticipated changes have no effect. The reaction of equity prices to the monetary policy surprise, though with the correct sign, is not significant (Table V). Both results, however, are not robust. For example, if the monetary policy surprise is proxied by the movement in the 3-month swap rate the impact on the exchange rate is no longer significant - though the fall in equity prices, by about 1.6 percent, is now significant. The lack of robust results is not new to the literature: Acuña and Pinto (2015), for example, finds no significant effects on stock prices from monetary policy shocks in Chile for the overall index, even though some sub-indexes react more.

Contrary to the effect on swap rates, we could not find a significant equity or FX market reaction to the IPoM (where the IPoM shocks are proxied by the movement in the 3-m swap rate on the dates of the IPoM release), possibly due to the short sample used.

Interestingly, Table VI shows that minutes have a strong negative, while mildly significant, impact on equity prices but only conditional on being "hawkish" (i.e., minutes that increase the 3-month swap rate on the release date). In the case of dovish minutes (i.e., minutes that reduce the 3-month swap rate), the impact has a flipped sign which means that the more dovish the minutes the lower the equity prices. ${ }^{29}$ This strong asymmetric result suggests that the information content of dovish minutes probably include information over state of the

\footnotetext{
${ }^{29}$ This result is robust to controlling for the GFC.
} 
economy rather than the CBC's Board's member preferences for looser monetary policy per se.

\section{MONETARY POLICY COMMUNICATION AND INFLATION DISPERSION}

The dispersion of inflation forecast is typically correlated with operators' inflation uncertainty. It is, thus, interesting to assess whether monetary policy decisions or communication affect the dispersion of inflation forecasts (in our cases measured as standard deviation across forecasts).

To answer the previous question, we regress two measures of dispersion of inflation forecasts at 12-month horizon on: its past values, the consensus forecast inflation level, and our constructed series of monetary policy surprises (i.e., the 3-month swap rate movement from IPoM and minutes releases, the median- and mean-forecast surprise from statements). ${ }^{30}$ All surprise series are then split into hawkish (i.e., above zero) and dovish surprises (i.e., below zero). ${ }^{31}$ Over our sample period, the average inflation dispersion is 0.28 point a standard deviation of 0.10 point, and a maximum of 0.68 point.

As expected both the lagged dispersion and the level of inflation have a positive coefficient and are highly significant (Table VII A and B). Both the IPoM and statement surprises have some effects once are split into hawkish and dovish surprises. The former are not significant but the latter reduce inflation dispersion significantly. A -25 bps surprise from IPoM increases inflation dispersion by 0.15 points. A -25 bps statement surprise, instead, increases the interquartile range by about 0.03 points.

\section{THE MACROECONOMIC IMPACT}

Finally, to study the transmission channel of monetary policy and its impact on economic activity and prices, it is necessary to isolate exogenous movements in the policy rate. The most traditional approach to identify monetary policy shocks relies on a timing assumption for which innovations to the monetary policy instrument - usually a short-term rate - have no contemporaneous effects on output and prices (see Christiano et al. 1999). This strategy is easily implemented in a VAR framework by using a recursive assumption where the policy instrument is ordered after measures of output and inflation.

Following the recent monetary policy literature (see Romer and Romer 2004, Coibion 2012, Gertler and Karadi 2015), however, we exploit our constructed series of monetary policy surprises which are designed to be orthogonal to output and inflation forecasts. ${ }^{32}$ This

\footnotetext{
${ }^{30}$ The two measures of inflation forecast dispersions are the interquartile range and the standard deviation of forecasts from Brito et al. (2017).

${ }^{31}$ We control for GFC period by dropping major loosening surprises (i.e., above $50 \mathrm{bps}$ ).

${ }^{32}$ It is also worth noting that the constructed series of surprises are not persistent (and, thus, forecastable). In fact, even if all surprise series constructed show some degree of autocorrelations, from 0.4 to 0.6 , this is mostly
}

(continued...) 
orthogonality, in turn, can be used to infer the causal effects of raising interest rates on economic activity and prices. Hence, we blend the traditional recursive identification strategy with the use of the monetary policy surprise data which act as an instrument for the change in the policy rate (this strategy is often referred to as proxy VAR).

In practice, we estimate a monthly VAR with an index of economic activity (IMACEC), the consumer price index (CPI), the constructed surprise series, the monetary policy rate (TPM), an end-of-period stock market index (IGPA), and the end-of-period peso-USD exchange rate (all variables are in logs). ${ }^{33}$ To trace the effect of a monetary policy shock on the economy we shock our monetary policy surprise series.

After a 100 bps monetary policy tightening shock, we find that the policy rate has an humpshaped reaction peaking at $30 \mathrm{bps}$ and returning to its original level after about 1 year (Figure 7). This persistent increase in the policy interest rate, in turn, implies a reduction in economic activity with a peak decline in the IMACEC of about $2 \mathrm{pp}$. after 1 year. ${ }^{34} \mathrm{CPI}$ 's response shows an initial price puzzle where prices increase, however, they revert their initial response and starts to decline after about 2 months ending up 1 percent lower after 2-3 years. The stock market declines by about 0.8 percent after 3 months, while the reaction of the exchange rate is not significant.

\section{CONCLUSION}

We have analyze the predictability and efficacy of the CBC's monetary policy by constructing a daily series of monetary policy surprises based on surveys and by identifying the movements in short-term rates at the time of the releases of the minutes and monetary policy report (IPoM). While both in isolation are not a guarantee of a successful communication policy, they can help you assess whether the communication framework is well functioning.

We have found that CBC's predictability is in general high (except during the GFC) and has increased over time as the number of surprise meetings has declined, as have the overall number of meetings with a change in the policy rate-even though macroeconomic volatility has not changed much. The efficacy of statements at times of monetary policy surprises is also quite high, since monetary policy surprises also affect the medium- and long-end of the yield curve more than other shocks. Forward guidance from statements seems to shift the entire yield curve while surprise actions tend to tilt rather than shift the curve. Minutes usually deliver a noisier signal while the IPoM provides substantial forward guidance for the policy rate inducing changes in medium- and long-term yields superior even to the ones

due a sequence of sizeable consecutive surprising policy cuts in the first quarter of 2009. If we remove them we find an autocorrelation around 0.2 that is not significant for the mean-forecast surprise.

${ }^{33}$ An alternative specification in log-difference gives similar results.

${ }^{34}$ As a matter of comparison, our magnitudes are similar to the one found by Coibion (2012) for the U.S. 
induced by "surprise" meetings. Results also suggest that inflation-forecast dispersion increases when markets are surprised by the CBC's dovish tone.

A 100 bps tightening surprise typically results in an appreciation of the exchange rate at impact by about 1.5 percent. The reaction of equity prices, in contrast, is not significant, though with the correct sign. Both results, however, are not robust.

Finally, using a proxy-VAR a la Gertler and Karadi (2015), we find that a 100 bps monetary policy tightening shock induces a hump-shaped response for the policy rate and a reduction in economic activity with a peak decline in the IMACEC of about $2 \mathrm{pp}$. after 1 year. In contrast, CPI fluctuates more, with prices increasing initially and then reverting after about 2 months and ending up 1 percent lower after 2-3 years. 


\section{REFERENCES}

Ball, Laurence M., and Niamh Sheridan. "Does inflation targeting matter?." The inflationtargeting debate. University of Chicago Press, 2004. 249-282.

Bernanke, Ben S., and Kenneth N. Kuttner. "What explains the stock market's reaction to Federal Reserve policy?" The Journal of Finance 60.3 (2005): 1221-1257.

Bernanke, Ben S., and Frederic S. Mishkin. "Inflation targeting: a new framework for monetary policy?." Journal of Economic perspectives 11.2 (1997): 97-116.

Blinder, Alan S., et al. "Central bank communication and monetary policy: A survey of theory and evidence." Journal of Economic Literature 46.4 (2008): 910-45.

Brito, Steve, Mr Yan Carriere-Swallow, and Bertrand Gruss. Disagreement about Future Inflation: Understanding the Benefits of Inflation Targeting and Transparency. International Monetary Fund, 2018.

Coibion, Olivier. "Are the Effects of Monetary Policy Shocks Big or Small?" American Economic Journal: Macroeconomics (2012): 1-32.

Christiano, Lawrence J., Martin Eichenbaum, and Charles L. Evans. "Monetary policy shocks: What have we learned and to what end?" Handbook of macroeconomics 1 (1999): 65-148.

De Gregorio, J. (2008). "Transparencia y Comunicaciones en la Banca Central Moderna", Documentos de Política Económica 25, Banco Central de Chile, July

Dincer, N. Nergiz, and Barry Eichengreen. "Central bank transparency and independence: updates and new measures." (2013).

Hayo, Bernd, and Matthias Neuenkirch. "Bank of Canada communication, media coverage, and financial market reactions." Economics Letters 115.3 (2012): 369-372.

Ehrmann, Michael, and Marcel Fratzscher. "Communication by central bank committee members: different strategies, same effectiveness?." Journal of Money, Credit and Banking 39.2-3 (2007): 509-541.

Garcia-Herrero, Alicia, Eric Girardin, and Hermann Gonzalez. "Analyzing the impact of monetary policy on financial markets in Chile." Revista de Análisis Económico-Economic Analysis Review 32.1 (2017): 3-22.

Gürkaynak, Refet S., Brian Sack, and Jonathan H. Wright. 2007. "The U.S. Treasury yield curve: 1961 to the present.” Journal of Monetary Economics 54 (8): 2291-2304. 
Gürkaynak, Refet S., Brian Sack, and Eric T. Swanson. 2005. "Do Actions Speak Louder than Words? The Response of Asset Prices to Monetary Policy Actions and Statements." International Journal of Central Banking 1 (1): 55-93.

Gertler, Mark, and Peter Karadi. 2013. “QE 1 vs. 2 vs. 3...: A Framework for Analyzing Large-Scale Asset Purchases as a Monetary Policy Tool.” International Journal of Central Banking 90 (1): 5-53.

Gertler, Mark, and Peter Karadi. "Monetary Policy Surprises, Credit Costs, and Economic Activity." American Economic Journal: Macroeconomics 7.1 (2015): 44-76. Dataset." American Economic Journal: Macroeconomics. http://dx.doi.org/10.1257/mac.20130329.

Kuttner, Kenneth N. 2001. "Monetary policy surprises and interest rates: Evidence from the Fed funds futures market.” Journal of Monetary Economics 47 (3): 523-44.

Larraín, Mauricio. "Sorpresas de política monetaria y la curva de rendimiento en Chile." Economía Chilena 10.1 (2007): 37-50.

Mertens, Karel, and Morten O. Ravn. "A reconciliation of svar and narrative estimates of tax multipliers." Journal of Monetary Economics 68 (2014): S1-S19.

Meyer de P, J. (2006). "Impacto de las Sorpresas Económicas en el Rendimiento de los Bonos del Banco Central de Chile”, Revista Economía Chilena 9 (2), Banco Central de Chile, August.

Morales, Marco, Carola Moreno, and Camilo Vio. "Foreign Shocks on Chilean Financial Markets: Spillovers and Comovements Between Bond and Equity Markets." Emerging Markets Finance and Trade 50 sup5 (2014): 35-50.

Ranaldo, Angelo, and Enzo Rossi. "The reaction of asset markets to Swiss National Bank communication." Journal of International Money and Finance 29.3 (2010): 486-503.

Rosa, Carlo. "Words that shake traders: The stock market's reaction to central bank communication in real time." Journal of Empirical Finance 18.5 (2011): 915-934. 


\section{FIGURES}

Figure 1 Monetary policy rate and surprise meetings

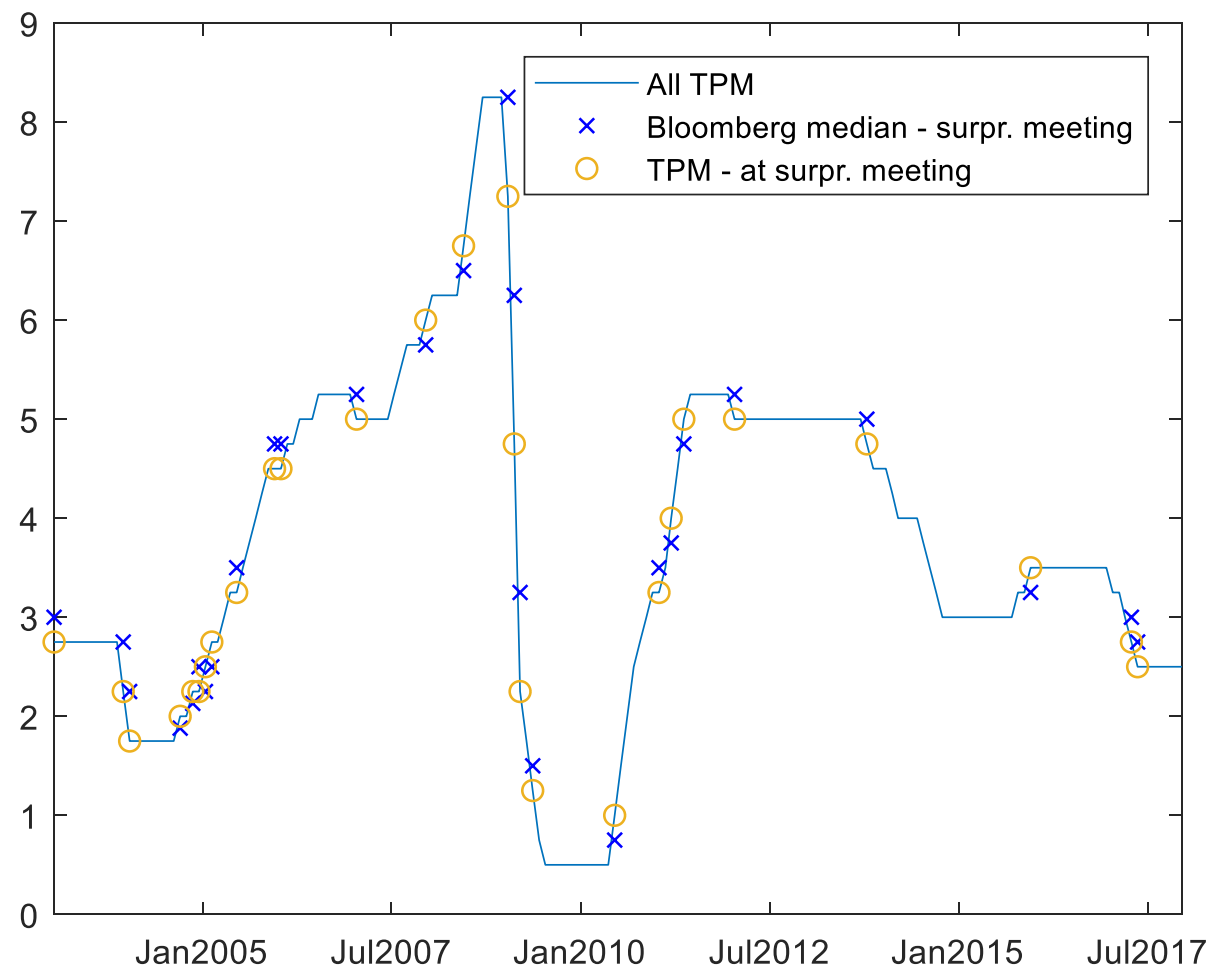

The blue line is the monetary policy rate, the " $\mathrm{x}$ " marker represents meetings where there was a surprise according to Bloomberg median-forecast surprises (yellow circles) the size of the surprise is indicated by the distance between yellow circles and the " $x$ " marker. Source Bloomberg and CBC. 
Figure 2 Monetary policy surprises and forecast disagreement
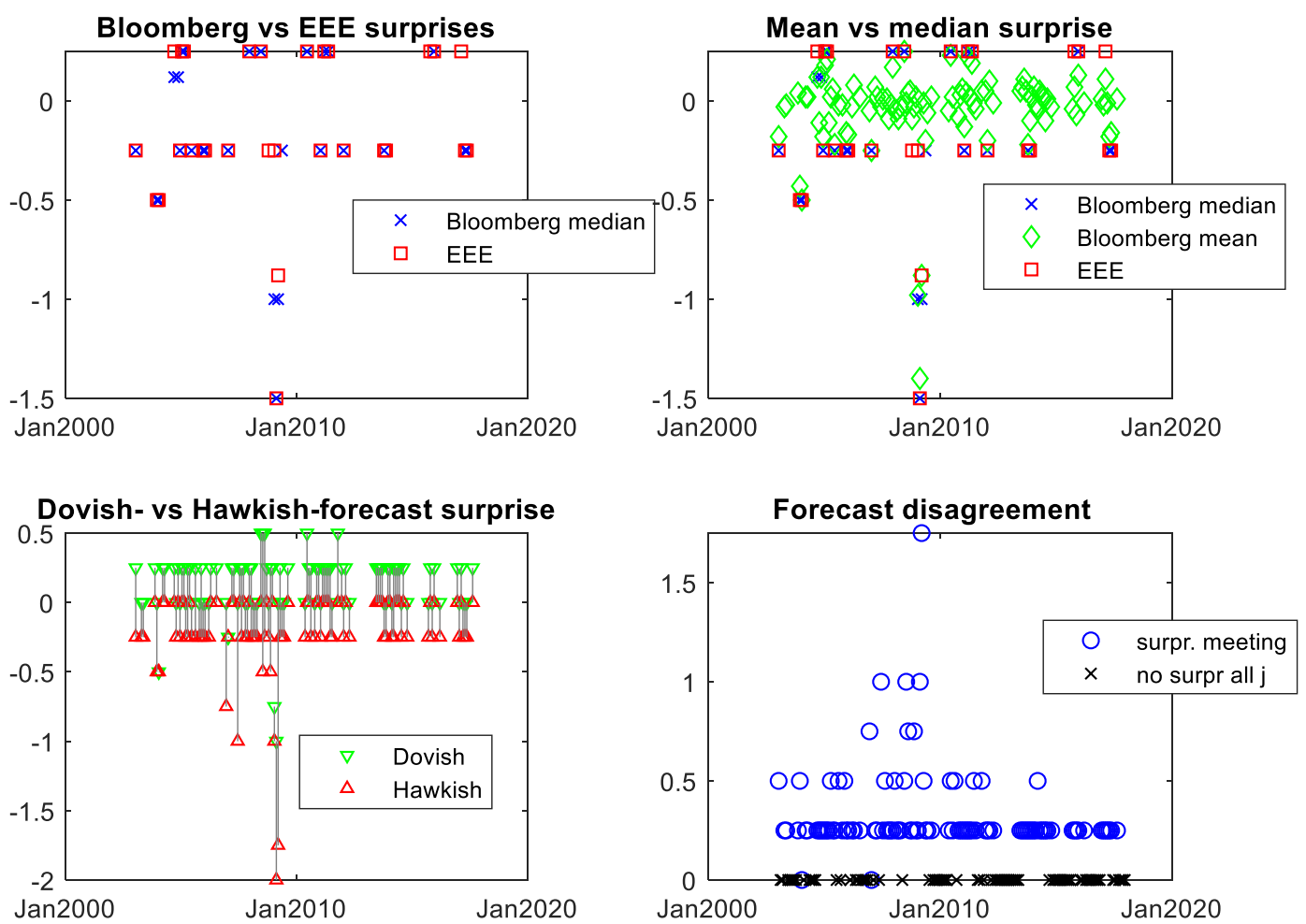

Top panel. Monetary policy surprises are constructed using the median and mean forecast from the Bloomberg survey and the median forecast from the EEE. Bottom panel. The highest (hawkish) and lowest (dovish) Bloomberg's policy rate forecast (bottom left panel); difference between the highest (hawkish) and lowest (dovish) Bloomberg's policy rate forecast at meetings with surprise (circles) and meetings with no surprise and no forecast disagreement (crosses) (bottom right panel); 
Figure 3. Monetary policy surprise distributions
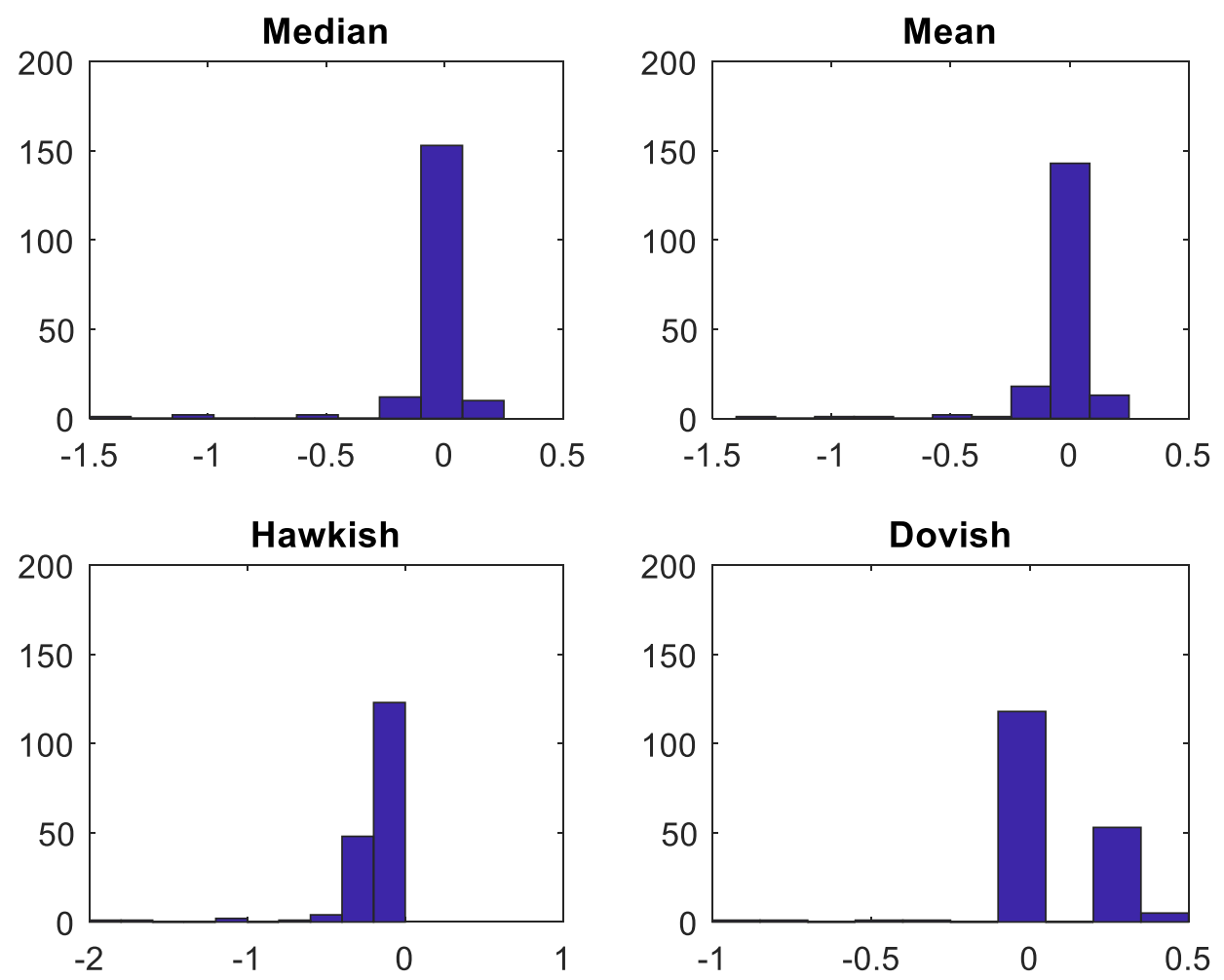

Monetary policy surprises are constructed using the median, mean, maximum, and minimum forecast from the Bloomberg survey. 
Figure 4 Secular trends in monetary policy surprises and reaction to inflation expectations.
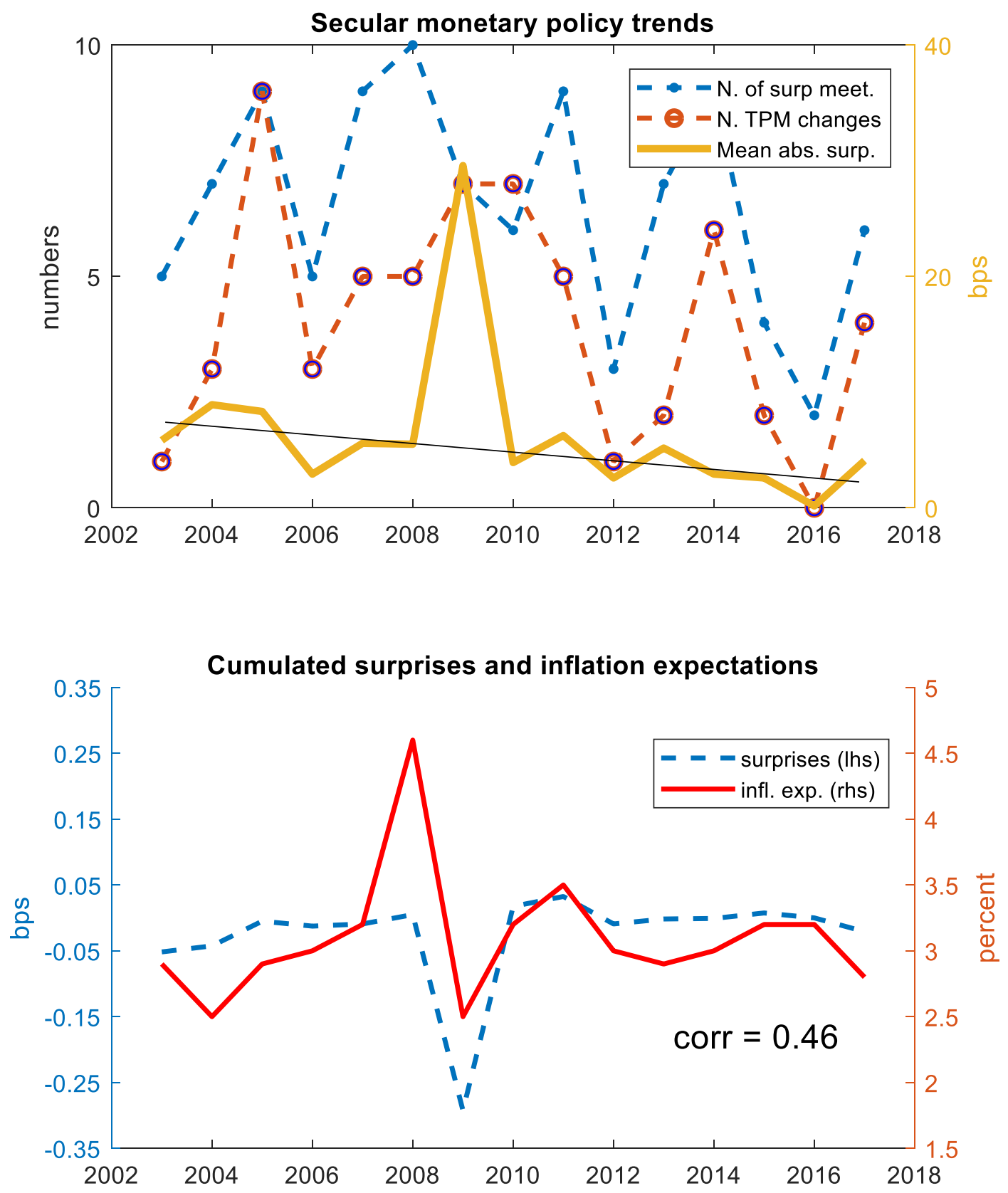

Top Panel: Total annual number of meeting with a median forecast surprise (Bloomberg survey), blue dashed line, total annual number of changes in the policy rate, dashed red line, annual averages of mean absolute surprises (Bloomberg survey), yellow solid line. Bottom Panel: cumulated median forecast surprise (Bloomberg survey), dashed blue line, and 12 month ahead inflation expectations (EEE), solid red line. 
Figure 5 Un-anticipated vs anticipated policy rate changes and 3-month swap rate.
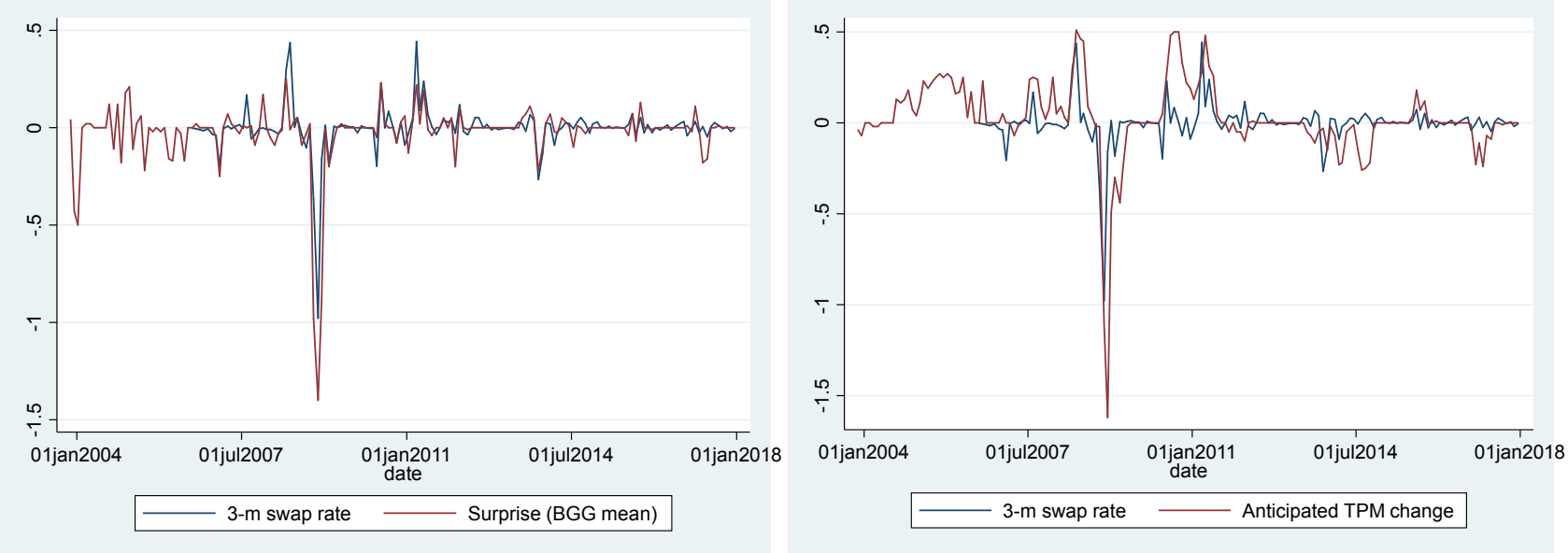

Left. Cleaned swap rate changes at 3-month maturity vs. Bloomberg mean-forecast surprises. Right. Cleaned swap rate changes at 3-month maturity vs the anticipated movement of the policy rate (TPM).

Figure 6 Swap rate changes on the release day of IPoMs and minutes

IPOM

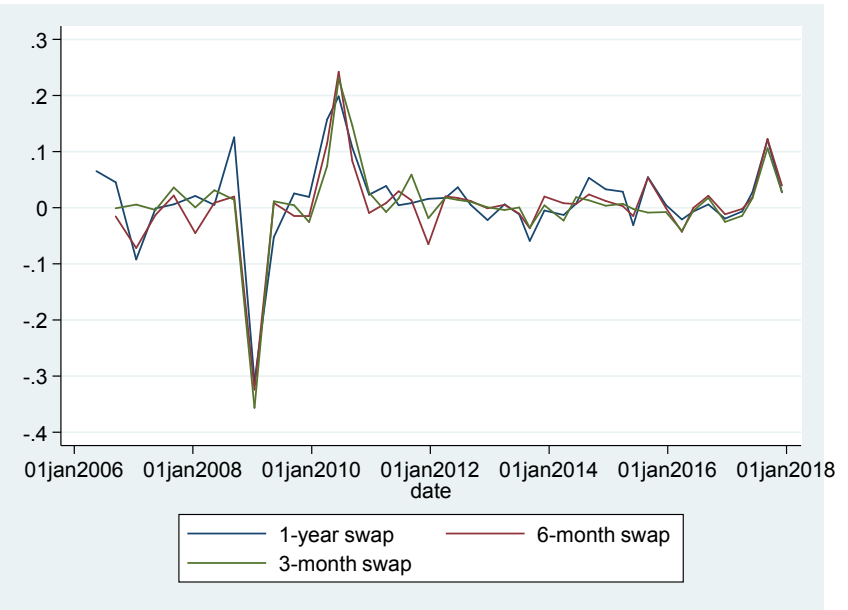

Minutes

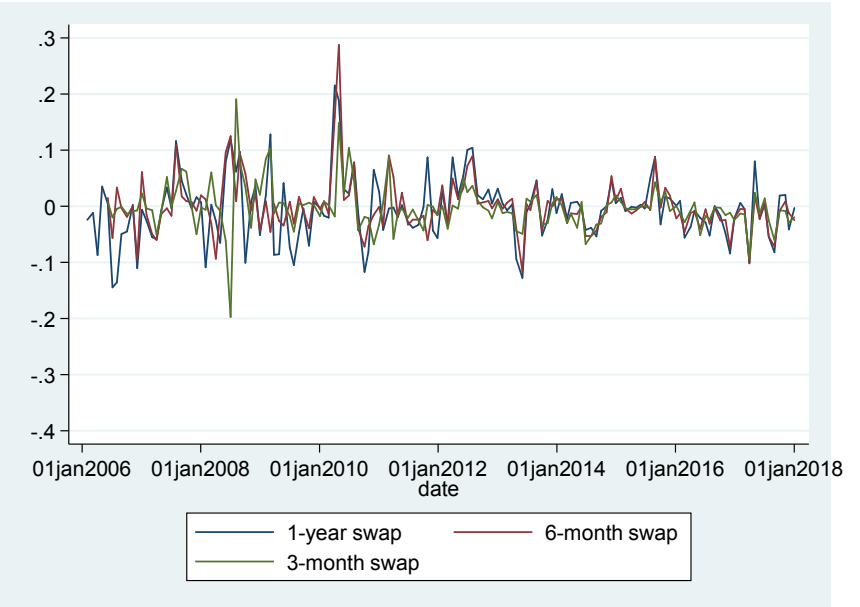

Left. Cleaned swap rate changes at 3-month 6-month and 1-year maturity the day of the IPoM release. Right. Cleaned swap rate changes at 3-month 6-month and 1-year maturity the day of the minutes release. 
Figure 8 IRF to a monetary policy shock instrumented by surprise
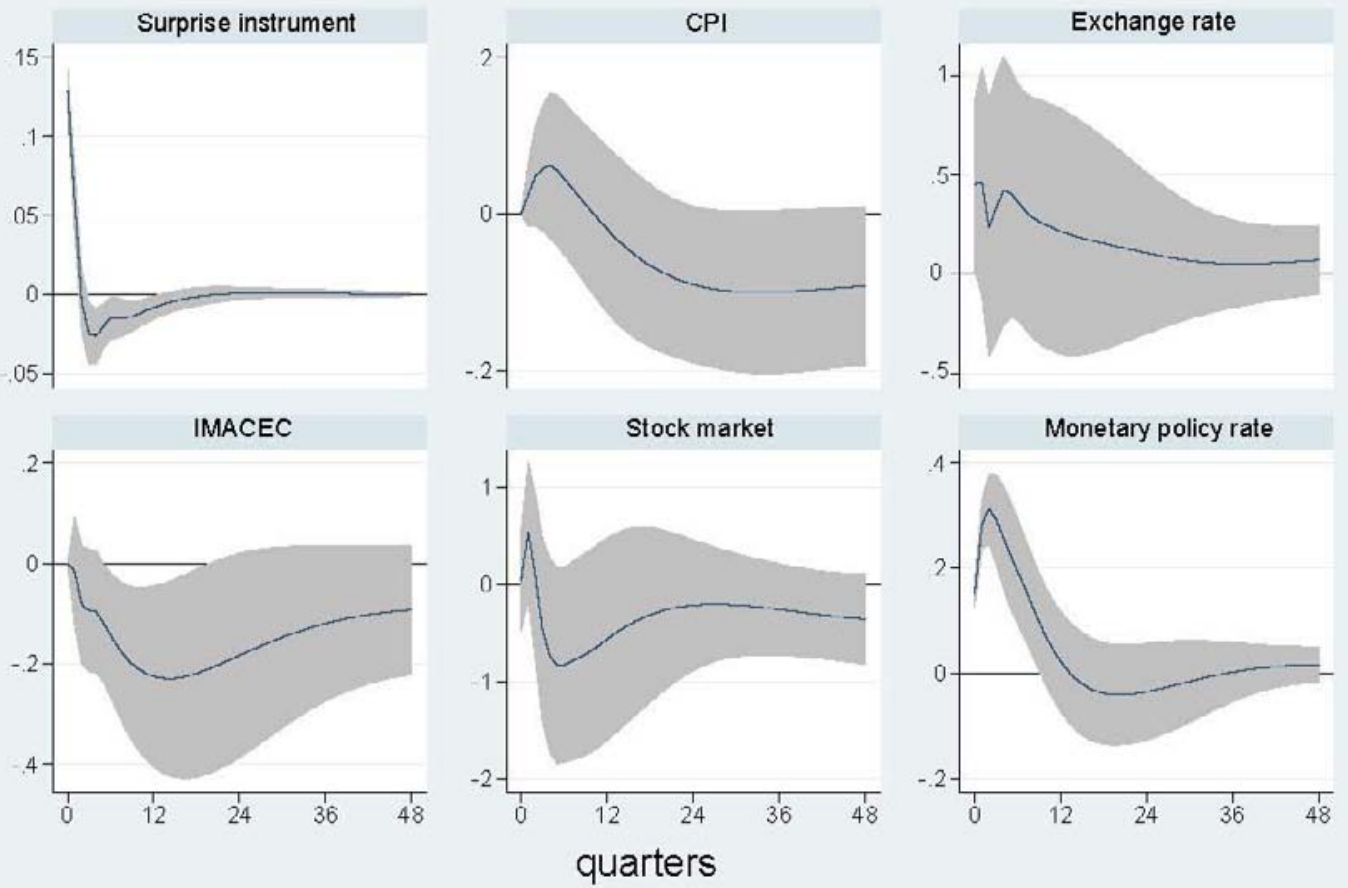

$95 \% \mathrm{Cl}$

orthogonalized iff 
Figure 9 Interest rate swaps, swap rates at different maturities and the monetary policy rate.

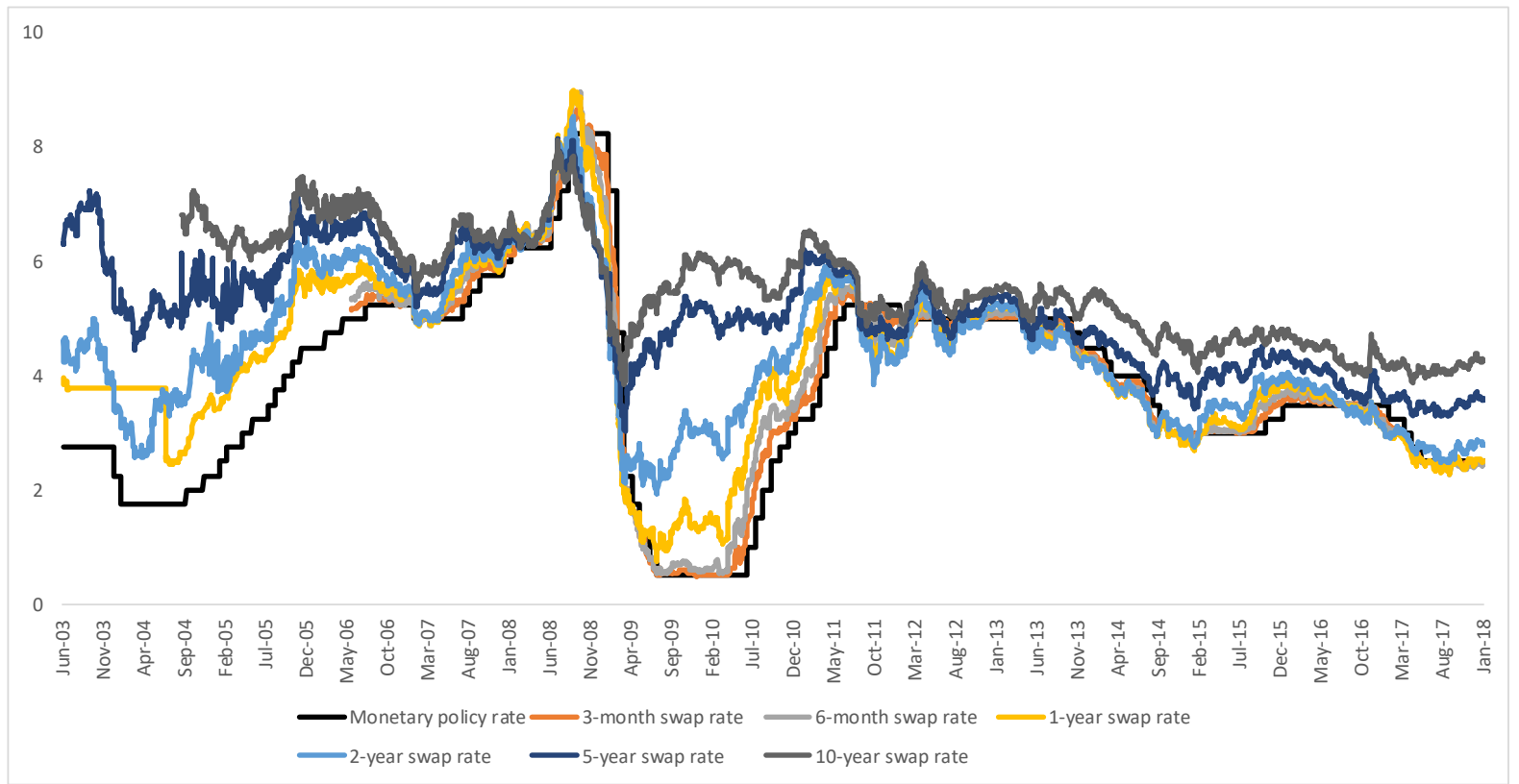

The black line is the monetary policy rate, other lines are swap rates at different maturities. Source HAVER and CBC. 


\section{TABLES}

Table I-A

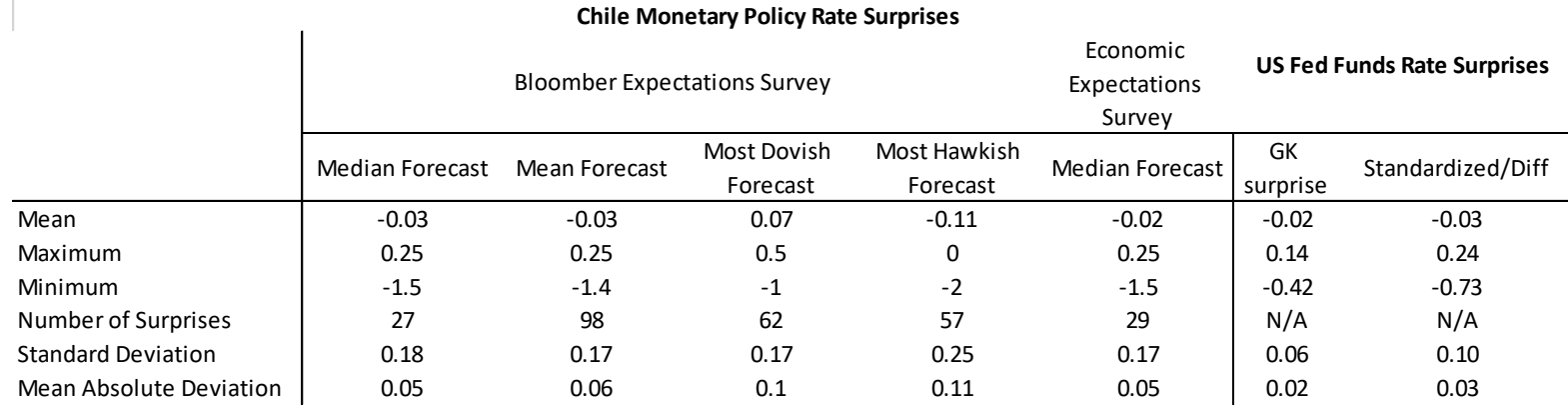

Sample 2003-2017, 180 events. Source CBC, Bloomberg, and IMF calculations. GK surprise is based on Gertler and Karadi (2015), the US results have been standardized dividing them by the ratio of the standard deviations of the US and Chile policy rate changes.

Table I-B

\begin{tabular}{|c|c|c|c|c|c|c|c|c|}
\hline & \multicolumn{4}{|c|}{ Some forecast dispersion } & \multicolumn{3}{|c|}{ No forecast dispersion } \\
\hline & & \multicolumn{2}{|c|}{ mean forecast } & \multicolumn{2}{|c|}{ median forecast } & \multicolumn{2}{|c|}{$i=j$ for all $i, j$} & \multirow[b]{2}{*}{ total } \\
\hline & & No surprise & surprise & No surprise & surprise & No surprise & surprise & \\
\hline \multirow{2}{*}{$\begin{array}{c}\text { monetary policy rate } \\
\text { decision }\end{array}$} & change & 2 & 50 & 31 & 21 & 6 & 2 & 60 \\
\hline & no change & 0 & 48 & 42 & 6 & 72 & 0 & 120 \\
\hline
\end{tabular}

No surprise means that the median (mean) policy rate forecast is equal to the actual. No forecast dispersion means all forecasts are equal. 
Table II Effects of monetary policy surprises on swap rates at various maturities

\begin{tabular}{|c|c|c|c|c|c|c|}
\hline VARIABLES & $\begin{array}{c}(1) \\
3 \text { month } \\
\text { swap }\end{array}$ & $\begin{array}{c}(2) \\
6 \text { month } \\
\text { swap }\end{array}$ & $\begin{array}{c}(3) \\
1 \text { year } \\
\text { swap }\end{array}$ & $\begin{array}{c}(4) \\
2 \text { year } \\
\text { swap }\end{array}$ & $\begin{array}{c}(5) \\
5 \text { year } \\
\text { swap }\end{array}$ & $\begin{array}{c}(6) \\
10 \text { year } \\
\text { swap }\end{array}$ \\
\hline Anticipated & $\begin{array}{c}0.0360 \\
(0.0335)\end{array}$ & $\begin{array}{c}-0.00164 \\
(0.0270)\end{array}$ & $\begin{array}{l}0.00900 \\
(0.0292)\end{array}$ & $\begin{array}{l}-0.0257 \\
(0.0352)\end{array}$ & $\begin{array}{c}0.0372 \\
(0.0338)\end{array}$ & $\begin{array}{l}-0.0270 \\
(0.0234)\end{array}$ \\
\hline Unanticipated & $\begin{array}{c}0.527^{* * *} \\
(0.0446)\end{array}$ & $\begin{array}{c}0.444^{* * *} \\
(0.0359)\end{array}$ & $\begin{array}{c}0.215^{* * *} \\
(0.0375)\end{array}$ & $\begin{array}{c}0.214^{* * *} \\
(0.0452)\end{array}$ & $\begin{array}{l}0.0728^{*} \\
(0.0435)\end{array}$ & $\begin{array}{c}0.0678 * * \\
(0.0313)\end{array}$ \\
\hline Constant & $\begin{array}{c}0.00979 \\
(0.00641)\end{array}$ & $\begin{array}{c}0.00593 \\
(0.00516)\end{array}$ & $\begin{array}{c}0.00710 \\
(0.00557)\end{array}$ & $\begin{array}{c}0.0123^{*} \\
(0.00671)\end{array}$ & $\begin{array}{l}-0.00480 \\
(0.00646)\end{array}$ & $\begin{array}{l}-0.00230 \\
(0.00459\end{array}$ \\
\hline $\begin{array}{l}\text { Observations } \\
\text { R-squared }\end{array}$ & $\begin{array}{c}138 \\
0.643\end{array}$ & $\begin{array}{c}138 \\
0.637\end{array}$ & $\begin{array}{c}174 \\
0.222\end{array}$ & $\begin{array}{c}174 \\
0.142\end{array}$ & $\begin{array}{c}174 \\
0.047\end{array}$ & $\begin{array}{c}159 \\
0.029\end{array}$ \\
\hline
\end{tabular}

Regressing swap rates on anticipated (unanticipated) monetary policy rate decisions, sample periods vary depending on data availability. Unanticipated movements (i.e. surprises) are constructed using mean-forecast Bloomberg survey data. Similar results obtained for a common sample period. 
Table III IPoM surprises and the yield curve

\begin{tabular}{|c|c|c|c|c|c|c|c|c|}
\hline VARIABLES & $\begin{array}{c}\text { (1) } \\
\text { 6-month }\end{array}$ & $\begin{array}{c}2) \\
6 \mathrm{~m} \\
\text { control }\end{array}$ & $\begin{array}{c}\text { (3) } \\
\text { 1-year }\end{array}$ & $\begin{array}{c}\text { (4) } \\
\text { 1y control }\end{array}$ & $\begin{array}{c}\text { (5) } \\
\text { 2-year }\end{array}$ & $\begin{array}{c}(6) \\
2 y \text { control }\end{array}$ & $\begin{array}{c}\text { (7) } \\
\text { 10-year }\end{array}$ & $\begin{array}{c}(8) \\
10 y \\
\text { control }\end{array}$ \\
\hline 3-m swap (IPoM) & $\begin{array}{c}0.921^{* * *} \\
(0.0538)\end{array}$ & & $\begin{array}{c}0.864^{* * *} \\
(0.0768)\end{array}$ & & $\begin{array}{c}0.683 * * * \\
(0.0971)\end{array}$ & & $\begin{array}{c}0.363^{* * *} \\
(0.0737)\end{array}$ & \\
\hline 3-m swap & & $\begin{array}{c}0.559 * * * \\
(0.0138)\end{array}$ & & $\begin{array}{c}0.468 * * * \\
(0.0178)\end{array}$ & & $\begin{array}{c}0.419 * * * \\
(0.0184)\end{array}$ & & $\begin{array}{c}0.258^{* * *} \\
(0.0180)\end{array}$ \\
\hline Constant & $\begin{array}{c}-0.00162 \\
(0.00396)\end{array}$ & $\begin{array}{l}-0.000452 \\
(0.000644)\end{array}$ & $\begin{array}{c}0.00670 \\
(0.00566)\end{array}$ & $\begin{array}{l}-0.000632 \\
(0.000835)\end{array}$ & $\begin{array}{l}-0.00201 \\
(0.00716)\end{array}$ & $\begin{array}{l}-0.000722 \\
(0.000862)\end{array}$ & $\begin{array}{l}-0.00828 \\
(0.00544)\end{array}$ & $\begin{array}{l}-0.000683 \\
(0.000842)\end{array}$ \\
\hline Observations & 43 & 3,037 & 43 & 3,037 & 43 & 3,037 & 43 & 3,037 \\
\hline R-squared & 0.877 & 0.352 & 0.755 & 0.185 & 0.547 & 0.146 & 0.372 & 0.063 \\
\hline
\end{tabular}

Standard errors in parentheses

$* * * p<0.01, * * p<0.05, * p<0.1$

Table IV Minutes surprises and the yield curve

\begin{tabular}{|c|c|c|c|c|c|c|c|c|}
\hline VARIABLES & $\begin{array}{c}\text { (1) } \\
\text { 6-month }\end{array}$ & $\begin{array}{c}(2) \\
6 \mathrm{~m} \\
\text { control }\end{array}$ & $\begin{array}{c}\text { (3) } \\
\text { 1-year }\end{array}$ & $\begin{array}{c}\text { (4) } \\
\text { 1y control }\end{array}$ & $\begin{array}{c}\text { (5) } \\
\text { 2-year }\end{array}$ & $\begin{array}{c}(6) \\
2 y \text { control } \\
\end{array}$ & $\begin{array}{c}\text { (7) } \\
\text { 10-year }\end{array}$ & $\begin{array}{c}(8) \\
10 y \\
\text { control }\end{array}$ \\
\hline 3-m swap (minut.) & $\begin{array}{c}0.415^{* * *} \\
(0.0932)\end{array}$ & & $\begin{array}{c}0.491 * * * \\
(0.111)\end{array}$ & & $\begin{array}{c}0.413^{* * *} \\
(0.113)\end{array}$ & & $\begin{array}{c}0.170^{*} \\
(0.0876)\end{array}$ & \\
\hline 3-m swap & & $\begin{array}{c}0.559 * * * \\
(0.0138)\end{array}$ & & $\begin{array}{c}0.468 * * * \\
(0.0178)\end{array}$ & & $\begin{array}{c}0.419 * * * \\
(0.0184)\end{array}$ & & $\begin{array}{c}0.258^{* * *} \\
(0.0180)\end{array}$ \\
\hline Constant & $\begin{array}{l}0.000315 \\
(0.00388)\end{array}$ & $\begin{array}{c}-0.000452 \\
(0.000644)\end{array}$ & $\begin{array}{c}-0.00384 \\
(0.00462)\end{array}$ & $\begin{array}{l}-0.000632 \\
(0.000835)\end{array}$ & $\begin{array}{c}0.00323 \\
(0.00471)\end{array}$ & $\begin{array}{l}-0.000722 \\
(0.000862)\end{array}$ & $\begin{array}{l}0.00605^{*} \\
(0.00364)\end{array}$ & $\begin{array}{c}-0.000683 \\
(0.000842)\end{array}$ \\
\hline Observations & 140 & 3,037 & 140 & 3,037 & 140 & 3,037 & 140 & 3,037 \\
\hline R-squared & 0.126 & 0.352 & 0.124 & 0.185 & 0.088 & 0.146 & 0.027 & 0.063 \\
\hline
\end{tabular}

Standard errors in parentheses

*** $p<0.01,{ }^{* *} p<0.05,{ }^{*} p<0.1$ 
Table V Effects of monetary policy statement surprises on stock and FX markets

\begin{tabular}{|c|c|c|c|c|}
\hline VARIABLES & $\begin{array}{l}\text { (1) } \\
\text { IGPA }\end{array}$ & $\begin{array}{l}\text { (2) } \\
\mathrm{FX}\end{array}$ & $\begin{array}{c}(3) \\
\text { IGPA-3m } \\
\text { swap } \\
\end{array}$ & $\begin{array}{c}(4) \\
\text { FX-3m } \\
\text { swap }\end{array}$ \\
\hline Anticipated & $\begin{array}{c}0.102 \\
(0.303)\end{array}$ & $\begin{array}{c}0.119 \\
(0.296)\end{array}$ & $\begin{array}{c}0.276 \\
(0.272)\end{array}$ & $\begin{array}{c}0.182 \\
(0.275)\end{array}$ \\
\hline Unanticipated & $\begin{array}{l}-0.814 \\
(0.573)\end{array}$ & $\begin{array}{c}-1.486 * * * \\
(0.559)\end{array}$ & & \\
\hline 3-m swap rate surprise & & & $\begin{array}{c}-1.585^{* *} \\
(0.651)\end{array}$ & $\begin{array}{l}-0.668 \\
(0.659)\end{array}$ \\
\hline Constant & $\begin{array}{l}-0.0224 \\
(0.0482)\end{array}$ & $\begin{array}{l}-0.00167 \\
(0.0471)\end{array}$ & $\begin{array}{l}-0.0134 \\
(0.0545)\end{array}$ & $\begin{array}{l}0.00159 \\
(0.0552)\end{array}$ \\
\hline $\begin{array}{l}\text { Observations } \\
\text { R-squared }\end{array}$ & $\begin{array}{c}175 \\
0.012\end{array}$ & $\begin{array}{c}175 \\
0.039\end{array}$ & $\begin{array}{c}137 \\
0.042\end{array}$ & $\begin{array}{c}137 \\
0.008\end{array}$ \\
\hline
\end{tabular}

Regressions (1) and (2): stock market index changes (IGPA) and Peso-USD changes on anticipated and un-anticipated policy rate decisions based on mean-forecast monetary policy surprises. Regressions (3) and (4), replacing mean-forecast monetary policy surprises with the 3-month swap rate surprise at statement releases. Sample periods varies depending on data availability.

Table VI Effects of monetary policy minutes surprises on stock and FX markets

\begin{tabular}{lcc}
\hline & $(1)$ & $(2)$ \\
& IGPA-3m & $\begin{array}{c}\text { FX-3m } \\
\text { SwarIABLES }\end{array}$ \\
\hline & swap & \\
3-month swap rate (+) & $-4.470^{*}$ & -2.857 \\
& $(2.264)$ & $(1.727)$ \\
3-month swap rate (-) & $7.390^{* * *}$ & $5.959^{* * *}$ \\
& $(2.671)$ & $(2.037)$ \\
Constant & $0.224^{* * *}$ & $0.112^{*}$ \\
& $(0.0811)$ & $(0.0619)$ \\
& & \\
Observations & 140 & 140 \\
R-squared & 0.064 & 0.065 \\
\hline Standard errors in parentheses & \\
$* * * p<0.01, * * p<0.05, * p<0.1$ &
\end{tabular}

Regressions (1) and (2): stock market index changes (IGPA) and Peso-USD changes on the 3 -month swap rate surprise at minutes release. 
Table VII-A Dispersion of inflation expectations, interquartile range

\begin{tabular}{|c|c|c|c|c|c|c|c|c|}
\hline VARIABLES & $\begin{array}{c}\text { (1) } \\
\text { Inf. disp }\end{array}$ & $\begin{array}{c}(2) \\
\text { Inf. disp } \\
\end{array}$ & $\begin{array}{c}\text { (3) } \\
\text { Inf. disp }\end{array}$ & $\begin{array}{c}(4) \\
\text { Inf. disp }\end{array}$ & $\begin{array}{c}\text { (5) } \\
\text { Inf. disp }\end{array}$ & $\begin{array}{c}(6) \\
\text { Inf. disp }\end{array}$ & $\begin{array}{c}(7) \\
\text { Inf. disp }\end{array}$ & $\begin{array}{c}(8) \\
\text { Inf. disp }\end{array}$ \\
\hline Inflation dispersion(t-1) & $\begin{array}{l}0.390^{* * *} \\
(0.0656)\end{array}$ & $\begin{array}{l}0.380^{* * *} \\
(0.0672)\end{array}$ & $\begin{array}{l}0.392 * * * \\
(0.0664)\end{array}$ & $\begin{array}{l}0.378 * * * \\
(0.0678)\end{array}$ & $\begin{array}{l}0.447 * * * \\
(0.0742)\end{array}$ & $\begin{array}{l}0.450 * * * \\
(0.0744)\end{array}$ & $\begin{array}{l}0.447 * * * \\
(0.0755)\end{array}$ & $\begin{array}{l}0.447^{* * *} \\
(0.0760)\end{array}$ \\
\hline Inflation expectation & $\begin{array}{c}0.0543^{* * *} \\
(0.0147)\end{array}$ & $\begin{array}{c}0.0539 * * * \\
(0.0147)\end{array}$ & $\begin{array}{c}0.0531^{* * *} \\
(0.0147)\end{array}$ & $\begin{array}{c}0.0521^{* * *} \\
(0.0147)\end{array}$ & $\begin{array}{c}0.0510^{* * *} \\
(0.0156)\end{array}$ & $\begin{array}{c}0.0512^{* * *} \\
(0.0156)\end{array}$ & $\begin{array}{c}0.0507^{* * *} \\
(0.0156)\end{array}$ & $\begin{array}{c}0.0507^{* * *} \\
(0.0170)\end{array}$ \\
\hline Median f. surprise & $\begin{array}{l}-0.106^{* *} \\
(0.0534)\end{array}$ & & & & & & & \\
\hline Median f. surprise (+) & & $\begin{array}{l}0.0149 \\
(0.180)\end{array}$ & & & & & & \\
\hline Median f. surprise (-) & & $\begin{array}{l}-0.121^{* *} \\
(0.0576)\end{array}$ & & & & & & \\
\hline Mean f. surprise & & & $\begin{array}{l}-0.0978 * \\
(0.0587)\end{array}$ & & & & & \\
\hline Mean f. surprise (+) & & & & $\begin{array}{l}0.0901 \\
(0.208)\end{array}$ & & & & \\
\hline Mean f. surprise (-) & & & & $\begin{array}{c}-0.122^{*} \\
(0.0642)\end{array}$ & & & & \\
\hline 3-m rate IPoM surprise & & & & & $\begin{array}{l}-0.126 \\
(0.258)\end{array}$ & & & \\
\hline 3-m rate IPoM surp. (+) & & & & & & $\begin{array}{l}-0.365 \\
(0.402)\end{array}$ & & \\
\hline 3-m rate IPoM surp. (-) & & & & & & $\begin{array}{l}0.0521 \\
(0.346)\end{array}$ & & \\
\hline 3-m rate minutes surprise & & & & & & & $\begin{array}{l}0.0292 \\
(0.259)\end{array}$ & \\
\hline 3-m rate minutes surp. $(+)$ & & & & & & & & $\begin{array}{l}0.0297 \\
(0.423)\end{array}$ \\
\hline $3-m$ rate minutes surp. (-) & & & & & & & & $\begin{array}{l}0.0285 \\
(0.473)\end{array}$ \\
\hline Constant & $\begin{array}{c}0.0174 \\
(0.0462)\end{array}$ & $\begin{array}{c}0.0198 \\
(0.0464)\end{array}$ & $\begin{array}{c}0.0215 \\
(0.0462)\end{array}$ & $\begin{array}{c}0.0243 \\
(0.0463)\end{array}$ & $\begin{array}{c}0.0147 \\
(0.0498)\end{array}$ & $\begin{array}{c}0.0151 \\
(0.0499)\end{array}$ & $\begin{array}{c}0.0160 \\
(0.0507)\end{array}$ & $\begin{array}{c}0.0160 \\
(0.0526)\end{array}$ \\
\hline Observations & 192 & 192 & 192 & 192 & 141 & 141 & 140 & 140 \\
\hline R-squared & 0.276 & 0.278 & 0.272 & 0.275 & 0.324 & 0.327 & 0.320 & 0.320 \\
\hline
\end{tabular}

Standard errors in parentheses

*** $p<0.01, * * p<0.05, * p<0.1$

Notes: The dependent variable, Inf. disp., is the interquartile range of 12-month ahead inflation expectations in the next month (Brito et al.

2017). The sample period is 2003-2017. 
Table VII-B Dispersion of inflation expectations, standard deviation

\begin{tabular}{|c|c|c|c|c|c|c|c|c|}
\hline VARIABLES & $\begin{array}{c}\text { (1) } \\
\text { Inf. disp }\end{array}$ & $\begin{array}{c}\text { (2) } \\
\text { Inf. disp } \\
\end{array}$ & $\begin{array}{c}\text { (3) } \\
\text { Inf. disp } \\
\end{array}$ & $\begin{array}{c}\text { (4) } \\
\text { Inf. disp } \\
\end{array}$ & $\begin{array}{c}\text { (5) } \\
\text { Inf. disp } \\
\end{array}$ & $\begin{array}{c}\text { (6) } \\
\text { Inf. disp } \\
\end{array}$ & $\begin{array}{c}\text { (7) } \\
\text { Inf. disp } \\
\end{array}$ & $\begin{array}{c}\text { (8) } \\
\text { Inf. disp } \\
\end{array}$ \\
\hline Inflation dispersion(t-1) & $\begin{array}{l}0.443 * * * \\
(0.0629)\end{array}$ & $\begin{array}{l}0.436 * * * \\
(0.0651)\end{array}$ & $\begin{array}{l}0.441^{* * *} \\
(0.0635)\end{array}$ & $\begin{array}{l}0.434^{* * *} \\
(0.0651)\end{array}$ & $\begin{array}{l}0.470 * * * \\
(0.0696)\end{array}$ & $\begin{array}{l}0.465^{* * *} \\
(0.0693)\end{array}$ & $\begin{array}{l}0.469 * * * \\
(0.0714)\end{array}$ & $\begin{array}{l}0.470 * * * \\
(0.0717)\end{array}$ \\
\hline Inflation expectation & $\begin{array}{l}0.0439 * * * \\
(0.00966)\end{array}$ & $\begin{array}{l}0.0439 * * * \\
(0.00969)\end{array}$ & $\begin{array}{l}0.0436 * * * \\
(0.00963)\end{array}$ & $\begin{array}{l}0.0434^{* * *} \\
(0.00966)\end{array}$ & $\begin{array}{c}0.0424^{* * *} \\
(0.0105)\end{array}$ & $\begin{array}{c}0.0421^{* * *} \\
(0.0105)\end{array}$ & $\begin{array}{c}0.0410^{* * *} \\
(0.0106)\end{array}$ & $\begin{array}{c}0.0417^{* * *} \\
(0.0116)\end{array}$ \\
\hline Median f. surprise & $\begin{array}{l}-0.0571 \\
(0.0352)\end{array}$ & & & & & & & \\
\hline Median f. surprise (+) & & $\begin{array}{r}-0.0123 \\
(0.116)\end{array}$ & & & & & & \\
\hline Median f. surprise (-) & & $\begin{array}{l}-0.0632 \\
(0.0384)\end{array}$ & & & & & & \\
\hline Mean f. surprise & & & $\begin{array}{l}-0.0617 \\
(0.0386)\end{array}$ & & & & & \\
\hline Mean f. surprise (+) & & & & $\begin{array}{c}-0.00425 \\
(0.134)\end{array}$ & & & & \\
\hline Mean f. surprise (-) & & & & $\begin{array}{l}-0.0696 \\
(0.0425)\end{array}$ & & & & \\
\hline 3-m rate IPoM surprise & & & & & $\begin{array}{c}-0.358^{* *} \\
(0.169)\end{array}$ & & & \\
\hline 3-m rate IPoM surp. (+) & & & & & & $\begin{array}{r}-0.0457 \\
(0.262)\end{array}$ & & \\
\hline 3-m rate IPoM surp. (-) & & & & & & $\begin{array}{c}-0.591 * * * \\
(0.225)\end{array}$ & & \\
\hline $3-\mathrm{m}$ rate minutes surprise & & & & & & & $\begin{array}{c}0.213 \\
(0.171)\end{array}$ & \\
\hline $3-\mathrm{m}$ rate minutes surp. $(+)$ & & & & & & & & $\begin{array}{c}0.180 \\
(0.278)\end{array}$ \\
\hline 3-m rate minutes surp. (-) & & & & & & & & $\begin{array}{c}0.253 \\
(0.314)\end{array}$ \\
\hline Constant & $\begin{array}{c}0.0164 \\
(0.0302)\end{array}$ & $\begin{array}{c}0.0176 \\
(0.0305)\end{array}$ & $\begin{array}{c}0.0180 \\
(0.0302)\end{array}$ & $\begin{array}{c}0.0191 \\
(0.0304)\end{array}$ & $\begin{array}{c}0.0147 \\
(0.0329)\end{array}$ & $\begin{array}{c}0.0141 \\
(0.0327)\end{array}$ & $\begin{array}{c}0.0195 \\
(0.0338)\end{array}$ & $\begin{array}{c}0.0182 \\
(0.0349)\end{array}$ \\
\hline Observations & 192 & 192 & 192 & 192 & 141 & 141 & 140 & 140 \\
\hline R-squared & 0.370 & 0.371 & 0.370 & 0.371 & 0.432 & 0.442 & 0.419 & 0.419 \\
\hline
\end{tabular}

Standard errors in parentheses

$* * * \mathrm{p}<0.01, * * \mathrm{p}<0.05, * \mathrm{p}<0.1$

Notes: The dependent variable, Inf. disp., is the standard deviation of 12-month ahead inflation expectations in the next month (see Brito et al

2017). The sample period is $2003-2017$ 
Table VIII-A robustness: Effects of monetary policy surprises on swap rates since 2010

\begin{tabular}{|c|c|c|c|c|c|}
\hline VARIABLES & $\begin{array}{c}\text { (1) } \\
3 \text { month } \\
\text { swap }\end{array}$ & $\begin{array}{c}(2) \\
6 \text { month } \\
\text { swap }\end{array}$ & $\begin{array}{c}(3) \\
1 \text { year } \\
\text { swap } \\
\end{array}$ & $\begin{array}{c}(4) \\
5 \text { year } \\
\text { swap } \\
\end{array}$ & $\begin{array}{c}5) \\
10 \text { year } \\
\text { swap } \\
\end{array}$ \\
\hline Anticipated surprises & $\begin{array}{c}0.0767^{* *} \\
(0.0371)\end{array}$ & $\begin{array}{c}0.0931 * * * \\
(0.0331)\end{array}$ & $\begin{array}{c}0.0367 \\
(0.0363)\end{array}$ & $\begin{array}{c}0.0135 \\
(0.0300)\end{array}$ & $\begin{array}{l}0.00541 \\
(0.0249)\end{array}$ \\
\hline Unanticipated surprises & $\begin{array}{c}0.762^{* * *} \\
(0.0816)\end{array}$ & $\begin{array}{c}0.713^{* * *} \\
(0.0728)\end{array}$ & $\begin{array}{c}0.579 * * * \\
(0.0799)\end{array}$ & $\begin{array}{c}0.0961 \\
(0.0661)\end{array}$ & $\begin{array}{c}0.0484 \\
(0.0548)\end{array}$ \\
\hline Constant & $\begin{array}{c}0.00625 \\
(0.00534)\end{array}$ & $\begin{array}{c}0.00615 \\
(0.00476)\end{array}$ & $\begin{array}{c}0.00809 \\
(0.00523)\end{array}$ & $\begin{array}{c}-0.00309 \\
(0.00433)\end{array}$ & $\begin{array}{l}-0.00324 \\
(0.00359)\end{array}$ \\
\hline $\begin{array}{l}\text { Observations } \\
\text { R-squared }\end{array}$ & $\begin{array}{c}95 \\
0.539\end{array}$ & $\begin{array}{c}95 \\
0.576\end{array}$ & $\begin{array}{c}95 \\
0.398\end{array}$ & $\begin{array}{c}95 \\
0.030\end{array}$ & $\begin{array}{c}95 \\
0.011\end{array}$ \\
\hline
\end{tabular}

Standard errors in parentheses

$* * * p<0.01,{ }^{* *} p<0.05, * p<0.1$

Table VIII-B robustness: Effects of monetary policy surprises on swap rates ex 2009Q1

\begin{tabular}{lccccc}
\hline & $\begin{array}{c}(1) \\
3 \text { month } \\
\text { swap }\end{array}$ & $\begin{array}{c}(2) \\
6 \text { month } \\
\text { swap }\end{array}$ & $\begin{array}{c}(3) \\
1 \text { year } \\
\text { swap }\end{array}$ & $\begin{array}{c}(4) \\
5 \text { year } \\
\text { swap }\end{array}$ & $\begin{array}{c}(5) \\
10 \text { year } \\
\text { swap }\end{array}$ \\
\hline \multirow{2}{*}{ VARIABLES } & & & & & \\
Anticipated surprises & $0.111^{* * *}$ & $0.0551^{*}$ & $0.0700^{* *}$ & $0.109^{* * *}$ & 0.0206 \\
& $(0.0332)$ & $(0.0279)$ & $(0.0307)$ & $(0.0393)$ & $(0.0270)$ \\
Unanticipated surprises & $0.709^{* * *}$ & $0.765^{* * *}$ & $0.354^{* * *}$ & $0.165^{* *}$ & 0.0882 \\
& $(0.0776)$ & $(0.0653)$ & $(0.0534)$ & $(0.0683)$ & $(0.0560)$ \\
Constant & 0.00577 & 0.00299 & 0.00532 & -0.00762 & -0.00457 \\
& $(0.00534)$ & $(0.00449)$ & $(0.00496)$ & $(0.00634)$ & $(0.00454)$ \\
Observations & & & & & \\
R-squared & 135 & 135 & 171 & 171 & 156 \\
\hline
\end{tabular}

Standard errors in parentheses

$* * * p<0.01, * * p<0.05, * p<0.1$

Table A1 and A2. Regressing swap rates on anticipated and un-anticipated policy rate decisions based on mean-forecast monetary policy surprises over different subsamples. Regressions in Table A1 are over the sub-sample 2010-2017; regressions in Table A2 are over the full sample but exclude 2009Q1. 
Table IX Robustness: Forward guidance effects of statements

\begin{tabular}{lcccccc}
\hline & $(1)$ & $(2)$ & $(3)$ & $(4)$ & $(5)$ & $(6)$ \\
VARIABLES & $\begin{array}{c}\text { month } \\
\text { swap }\end{array}$ & $\begin{array}{c}6 \text { month } \\
\text { swap }\end{array}$ & $\begin{array}{c}1 \text { year } \\
\text { swap }\end{array}$ & $\begin{array}{c}2 \text { year } \\
\text { swap }\end{array}$ & $\begin{array}{c}5 \text { year } \\
\text { swap }\end{array}$ & $\begin{array}{c}10 \text { year } \\
\text { swap }\end{array}$ \\
\hline \multirow{3}{*}{ 3-m swap } & & & & & & \\
& & $1.138^{* * *}$ & $1.525^{* * *}$ & $1.511^{* * *}$ & $1.208^{* * *}$ & $0.881^{* * *}$ \\
surprise dummy & & $(0.205)$ & $(0.283)$ & $(0.242)$ & $(0.232)$ & $(0.207)$ \\
& 0.0170 & -0.000507 & 0.0120 & 0.0151 & -0.00933 & -0.00463 \\
3-mXdummy & $(0.0128)$ & $(0.00865)$ & $(0.0120)$ & $(0.0102)$ & $(0.00979)$ & $(0.00874)$ \\
& & $-0.767^{* * *}$ & $-1.331^{* * *}$ & $-1.345^{* * *}$ & $-1.102^{* * *}$ & $-0.721^{* * *}$ \\
Unanticipated surprise & $0.535^{* * *}$ & $(0.205)$ & $(0.284)$ & $(0.243)$ & $(0.233)$ & $(0.208)$ \\
& $(0.0449)$ & $(0.0432)$ & $(0.0597)$ & $(0.0510)$ & $(0.0489)$ & $(0.0436)$ \\
Anticipated surprise & 0.0316 & -0.00886 & -0.0136 & -0.0353 & 0.00898 & $-0.0512^{* *}$ \\
& $(0.0336)$ & $(0.0227)$ & $(0.0313)$ & $(0.0268)$ & $(0.0257)$ & $(0.0229)$ \\
Constant & 0.000259 & 0.00288 & 0.000224 & -0.00600 & -0.00306 & -0.00234 \\
& $(0.0096)$ & $(0.00644)$ & $(0.00891)$ & $(0.00761)$ & $(0.00730)$ & $(0.00651)$ \\
Observations & & & & & & \\
R-squared & 138 & 138 & 138 & 138 & 138 & 138 \\
\hline Standard & 0.648 & 0.755 & 0.412 & 0.393 & 0.238 & 0.204 \\
\hline
\end{tabular}

Standard errors in parentheses

$* * * \mathrm{p}<0.01, * * \mathrm{p}<0.05, * \mathrm{p}<0.1$

Surprises are constructed using the mean-forecast surprise. The surprise dummy takes the value of 1 if there was at least some surprise and zero otherwise. The line "3-mXdummy" represents the interaction term between the surprise dummy and the 3-month swap rate. Of the 138 observations, 79 had a surprise meeting. 